\title{
GROUND-WATER HYDROLOGY OF THE AREA BORDERING THE OHIO RIVER BETWEEN KENOVA AND
}

\section{WAVERLY, WEST VIRGINIA}

By Melvin V. Mathes, Robert A. Shultz, and John S. Bader

U.S. GEOLOGICAL SURVEY

Open-File Report 95-711

Prepared in cooperation with the

WESK VIRGINIA DIVISION OF ENVIRONMENTAL PROTECTION, OFFICE OF WATER RESOURCES

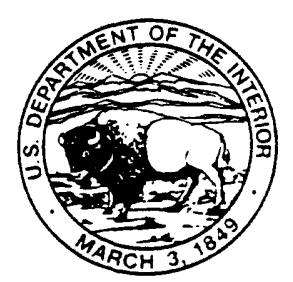

Charleston, West Virginia 


\section{U.S. DEPARTMENT OF THE INTERIOR \\ BRUCE BABBITT, Secretary \\ U.S. GEOLOGICAL SURVEY \\ Gordon P. Eaton, Director}

For additional information write to:

District Chief

U.S. Geological Survey, WRD

11 Dunbar Street

Charleston, WV 25301
Copies of the report can be purchased from:

U.S. Geological Survey

Earth Science Information Center

Open-File Reports Section

Box 25286, MS 517

Denver Federal Center

Denver, CO 80225 


\section{CONTENTS}

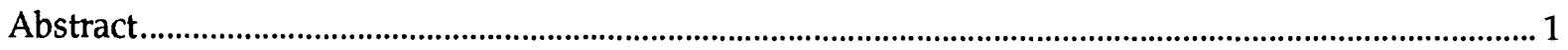

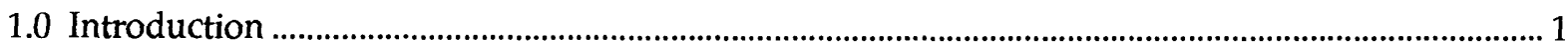

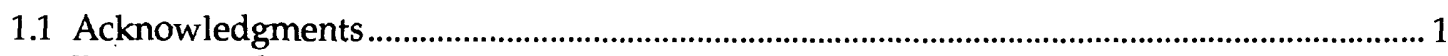

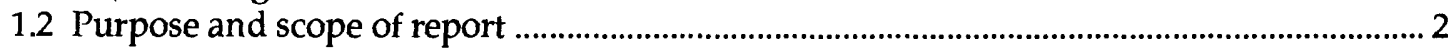

1.3 Location and general features of project area ........................................................................... 2

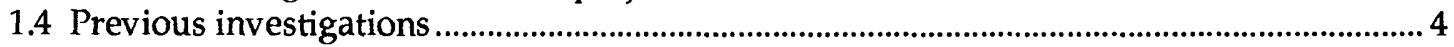

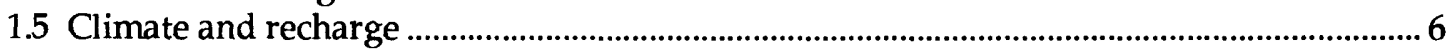

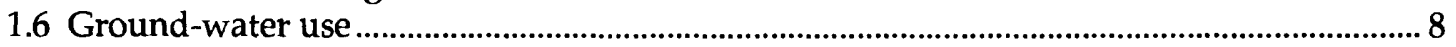

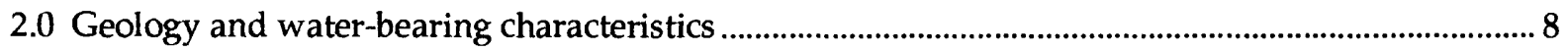

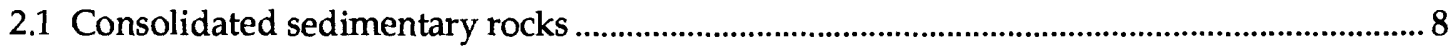

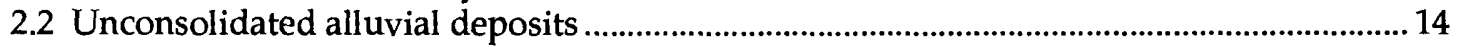

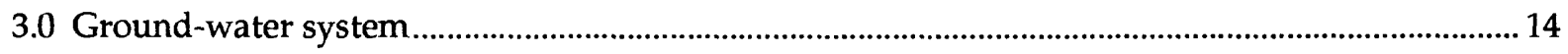

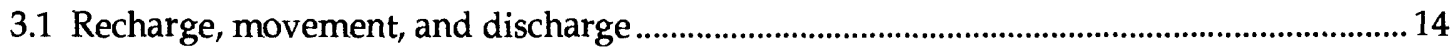

3.2 Hydraulic characteristics of alluvial aquifer......................................................................... 20

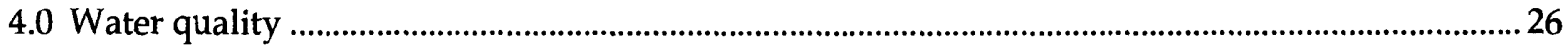

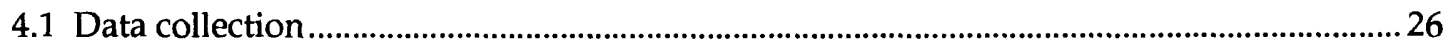



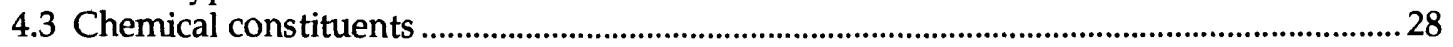

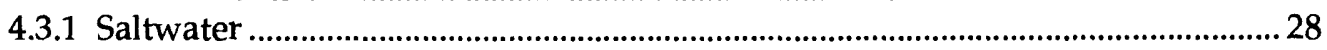

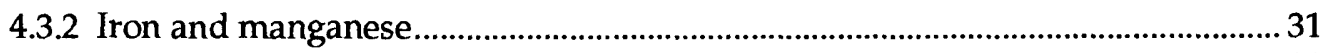

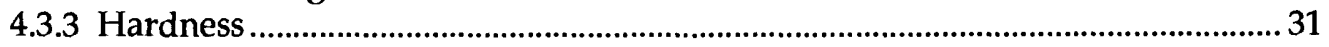

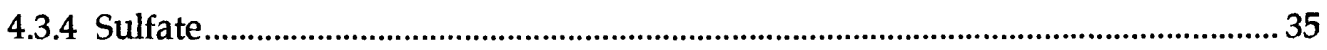

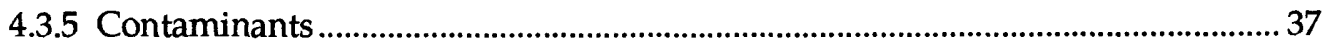

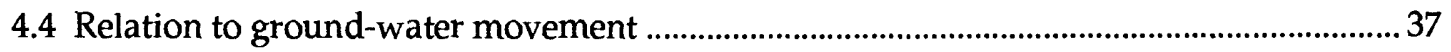

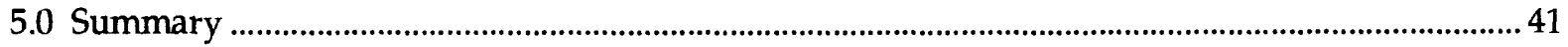

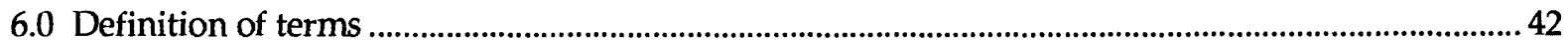

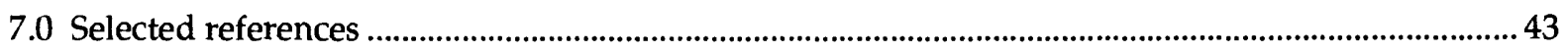




\section{ILLUSTRATIONS}

Figure 13-1 Map showing location of project area Page

1.4-1 Map showing areas covered by published geologic and hydrologic reports..................3

15-1 Graphs showing mean monthly precipita

1.6-1 Map showing location of public-supply wells ..................................................................

2.2-1 Map showing drillers' logs of selected wells in the alluvium along the

Ohio River in western West Virginia ..................................................................... 15

3.1-1 Hydrographs showing ground-water levels and river stage near

Point Pleasant, October 1978 to September 1980 ....................................................... 19

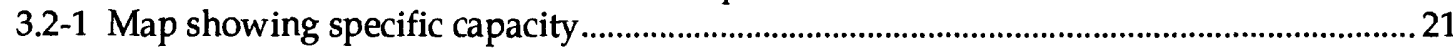



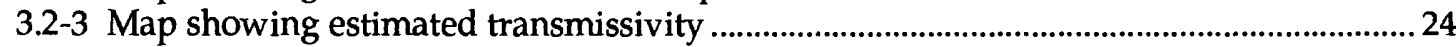

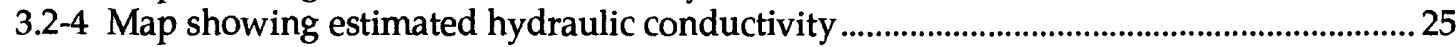

4.2-1 Map showing areal distribution of cations and anions .................................................2 27

4.3.1-1 Map showing areal distribution of dissolved chloride..................................2 29

4.3.1-2 Sketch showing relation between freshwater and saltwater ......................... 30

4.3.2-1 Map showing areal distribution of dissolved iron........................................... 32

4.3.2-2 Map showing areal distribution of dissolved manganese .............................33

4.3.3-1 Map showing areal distribution of hardness ................................................... 34

4.3.4-1 Map showing areal distribution of dissolved sulfate ................................... 36

4.3.5-1 Map showing areas where selected contaminant concentration

exceeds established State limits................................................................ 38

4.4-1 Trilinear water-analysis diagram of water samples from the

alluvium, bedrock, and Ohio River ........................................................................ 40

TABLE

Page

Table 1.5-1 Mean monthly precipitation and evapotranspiration. 6 


\section{CONVERSION FACTORS AND VERTICAL DATUM}

\section{Multiply}

inch (in.)

foot (ft)

mile (mi)

square mile $\left(\mathrm{mi}^{2}\right)$

gallon (gal)

million gallons (Mgal)

cubic foot $\left(\mathrm{ft}^{3}\right)$

cubic mile $\left(\mathrm{mi}^{3}\right)$

acre-foot (acre-ft)

cubic foot per second $\left(\mathrm{ft}^{3} / \mathrm{s}\right)$

gallon per minute ( $\mathrm{gal} / \mathrm{min}$ )

million gallons per day (Mgal/d)

gallon per minute per foot $[(\mathrm{gal} / \mathrm{min}) / \mathrm{ft}]$ foot per day (ft/d)

foot squared per day $\left(\mathrm{ft}^{2} / \mathrm{d}\right)$
By

Length

25.4

0.3048

1.609

Area

2.590

Volume

3,785

0.02832

4.166

1,233

Flow

28.32

0.06308

43.81

Aquifer characteristics

0.207

0.305

0.0929
To

millimeter

meter

kilometer

square kilometer

liter

cubic meter

cubic meter

cubic kilometer

cubic meter

liter per second

liter per second

cubic decimeter per second

liter per second per meter meter per day

meter squared per day

Temperature in degrees Fahrenheit $\left({ }^{\circ} \mathrm{F}\right)$ can be converted to degrees Celsius $\left({ }^{\circ} \mathrm{C}\right)$ as follows:

$$
{ }^{\circ} \mathrm{F}=1.8 \times{ }^{\circ} \mathrm{C}+32
$$

Sea level : In this report "sea level" refers to the National Geodetic Vertical Datum of 1929 (NGVD of 1929)--a geodetic datum derived from a general adjustment of the first-order level nets of both the United States and Canada, formerly called "Sea Level of 1929." liter $(\mu \mathrm{g} / \mathrm{L})$.

Chemical concentration in water is expressed in milligrams per liter $(\mathrm{mg} / \mathrm{L})$ and micrograms per 


\title{
GROUND-WATER HYDROLOGY OF THE AREA BORDERING
}

\author{
THE OHIO RIVER BETWEEN KENOVA AND
}

\author{
WAVERLY, WEST VIRGINIA
}

By Melvin V. Mathes, Robert A. Shultz, and John S. Bader

\begin{abstract}
Ground-water reserves in West Virginia are contained in the consolidated rock underlying the State and in the alluvium bordering the Ohio and Kanawha Rivers. Ground-water use in the study area, which includes parts of Cabell, Jackson, Mason, Wayne, and Wood Counties in western West Virginia, was estimated to be 9 billion gallons in 1983. The consolidated rock (bedrock) that crops out in the study area is of Pennsylvanian or Permian age. Alluvial deposits in the study area are limited mostly to the flood plain of the Ohio River. The alluvium is not vertically homogeneous; the lower part of the deposits consists of sand and gravel of glacial outwash origin, and the upper deposits consist of clay and silt interspersed with sand stringers. In some areas, the tributary streams have deposited a gravel delta where they enter the valley of the Ohio River. Ground water flows from the adjacent hills toward the river. The alluvium is recharged by the following sources: (1) precipitation on the flood plain, (2) inflow from fractures in the bedrock beneath and adjacent to the alluvium, (3) inflow from tributary streams through gravel deltas and bedding-plane partings, and (4) induced inflow from the river. In some ground-water samples, concentrations of iron, manganese, sulfate, nitrate, barium, and phenols exceeded recommended limits for drinking water established by the West Virginia State Board of Health. Ground-water hardness exceeded 120 milligrams per liter in 78 percent of the samples.
\end{abstract}

\subsection{INTRODUCTION}

\subsection{Acknowledgments}

The authors appreciate the cooperation of the many corporations, municipalities, and private well owners who provided information about their wells and permitted samples of water to be taken for analysis. The cooperation of many well drillers who provided well logs and well construction data also is acknowledged. Special appreciation is given to Mr. Edward Norman, who provided typed descriptions of several of the wells his family drilled. Special thanks is also given to Mr. Earl Mayle, who provided logs and descriptions for several of the wells he drilled. 


\subsection{Purpose and Scope of Report \\ PROTECTION OF PUBLIC WATER SUPPLY IS PRIMARY CONCERN}

The geologic and hydrologic properties of an aquifer system must be understood so it can be fully used and protected from overdevelopment and contamination.

Most ground water in West Virginia is derived from two aquifer systems. The most widespread is the system of fractures in the consolidated rock (bedrock) that underlies the State. The other is the narrow band of alluvium that borders the Ohio and Kanawha Rivers. Both aquifer systems can be contaminated by percolation or injection of harmful materials, and both can become uneconomical for water supply by overuse.

This report describes the results of an investigation to improve understanding of the hydrologic properties of the aquifer systems in the study area. Sensible and orderly development of the ground-water resources of an area requires a thorough understanding of the geology and hydrology of the area. The adequacy of a ground-water supply can be affected by many natural and humaninduced processes. An understanding of the hydrologic environment can aid in making sound decisions that would protect the ground-water resources of an area from detrimental practices.

The scope of the work included ground-water data collection from numerous sources. Selected wells in the study area were visited. Details of well construction were obtained from the owners and, where possible, depth to water was measured. If available, additional information on well construction was obtained from the driller. Water from many of the wells was analyzed for selected inorganic and organic chemical constituents. Reports from previous studies in the area were obtained, as were reports on other alluvial aquifers in and near the Ohio River drainage. Data also were obtained from the files of the U.S. Geological Survey; the West Virginia Department of Natural Resources, Division of Water Resources; and the West Virginia Department of Health. Those data, together with those collected as part of this project, were analyzed and are reported herein.

\subsection{Location and General Features of Project Area \\ PROJECT AREA IS IN WESTERN WEST VIRGINIA AND INCLUDES PARTS OF FIVE COUNTIES}

The area extends from Kenova to Waverly, West Virginia.

The project area is the West Virginia side of the Ohio River valley from Kenova to Waverly (fig. 1.3-1). It includes parts of Cabell, Jackson, Mason, Wayne, and Wood Counties. The combined 1980 population of these counties is approximately 300,000 . Approximately half of this population lives close to the Ohio River. The larger population centers include Huntington, Parkersburg, Vienna, and Point Pleasant.

The area is part of the highly industrialized Ohio River valley. It contains major facilities for the manufacture and processing of aluminum, rubber, glass, and chemicals, as well as coal mines and coal-fired, electric-power generating plants. 


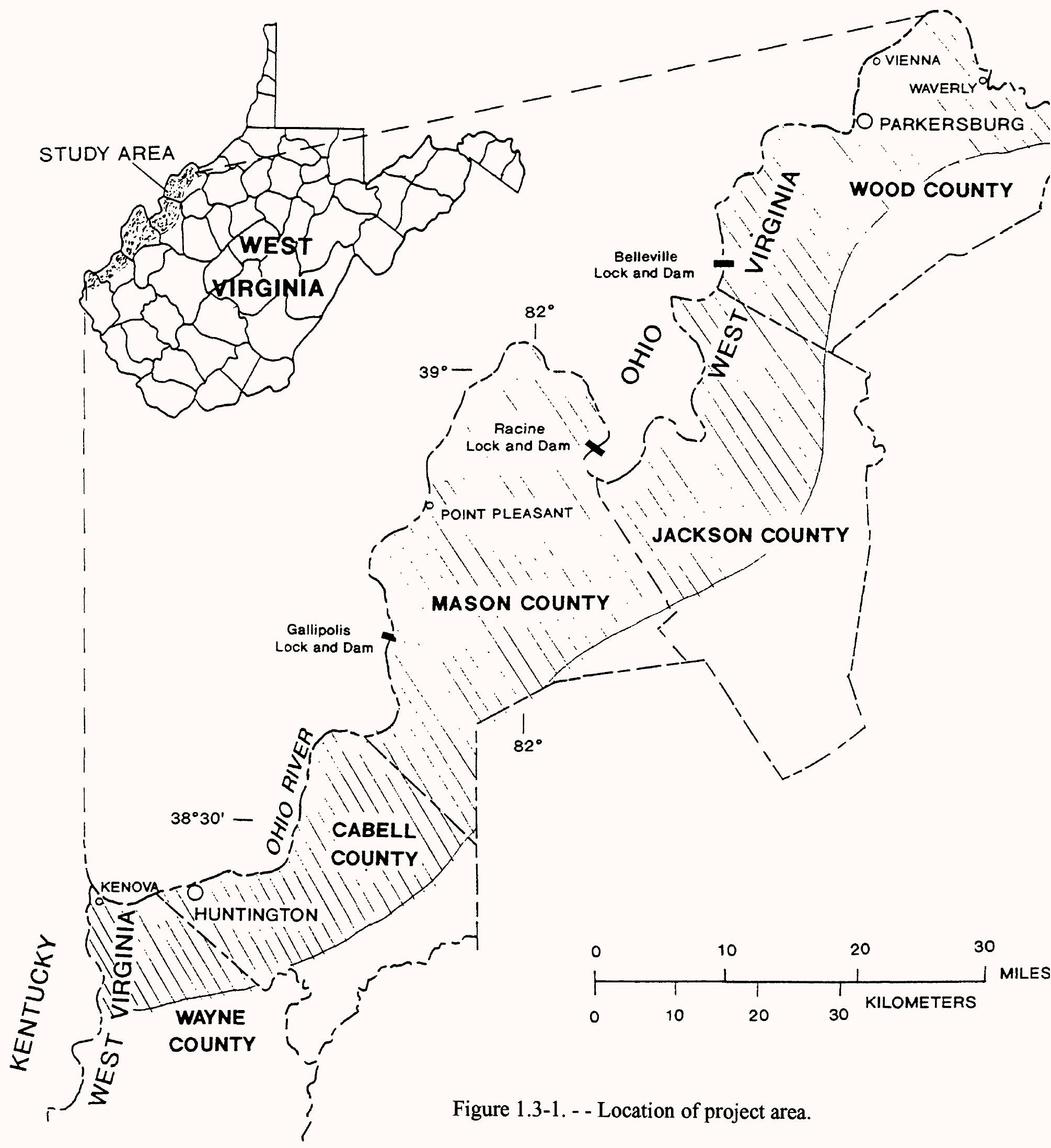


The topography of the area adjacent to the flat Ohio River flood plain is the typical hilly terrain found in the dissected Appalachian Plateaus physiographic province (Fenneman and Johnson, 1946). Maximum relief of the hills is about 500 feet. The flood plain is about 1.3 miles wide at its widest point. The elevation of the flood plain ranges from about 520 feet above sea level at Kenova to about 600 feet above sea level at Waverly. The elevation of the Ohio River in the area is controlled by four locks and dams with the following pool elevations (above sea level): Greenup, Kentucky, downstream of the study area, 515 feet; Gallipolis, 538 feet; Racine, 560 feet; and Belleville, 582 feet.

\subsection{Previous Investigations}

\section{NUMEROUS STUDIES HAVE BEEN MADE OF THE GEOLOGY AND HYDROLOGY OF THE AREA}

The geology of the area was studied in detail in the early part of the century, and, more recently, the hydrology has been studied in basinwide, countywide, and local projects.

The geology of the study area is described in three county reports by Krebs (1911 and 1913) and Grimsley (1910), and it is also shown on the "1968 Geologic Map of West Virginia" (Cardwell and others, 1968).

The geologic units beneath the rocks saturated by freshwater are discussed in oil and gas reports of the counties in the project area, including those by Haught (1955) and Overbey (1961).

A description of the hydrology of the entire Ohio River basin is published in the "Ohio River Basin Comprehensive Survey" (Deutsch and others, 1966; Dove and Wallace, 1966; and Wallace and others, 1966). The part of the Ohio River valley that lies in West Virginia is described in the three-part report by the West Virginia Geological Survey, Volume XXII, titled "Geology and Economic Resources of the Ohio River Valley in West Virginia" (West Virginia Geological and Economic Survey, 1956). The geology is described in Part I by Cross and Schemel (1956), and the ground-water resources are described in Part III by Carlston and Graeff (1955). An atlas by Shultz (1984) describes the geology and ground-water hydrology of the minor tributary basins of the Ohio River. Four additional atlases describe the geology and ground-water hydrology of the major tributary basins of the Ohio River. Hobba (1980) describes the Little Kanawha basin, Ferrell (1984) describes the Kanawha basin, and Bader (1984a, 1984b) describes the Guyandotte basin and the Tug Fork and Twelvepole Creek basins. Areas described by several of the preceding reports are shown in figure 1.4-1.

Numerous reports that,discuss the geology and hydrology of alluvial aquifers outside this project area are available. Some are listed as selected references in this report (section 7.0). Among the more noteworthy are: Gallaher and Price (1966), Crain (1966), Rorabaugh (1946 and 1948), Norris and Fidler (1969), Whitesides and Ryder (1969), Grubb and Zehner (1973), and Norris and Eagon (1971). 


\section{LARGER AREAS COVERED BY PUBLISHED GEOLOGIC AND HYDROLOGIC REPORTS}

- Ohio River Drainage between Marietta and Point Pleasant (Dove and Wallace, 1966)

- Geologic map of West Virginia (Cardwell and others, 1968)

- Ohio River drainage in West Virginia (Carlston and Graeff, 1955) (Cross and Schemel, 1956) (Deutsch and others, 1966)

- Ohio River Drainage between Point Pleasant and Maysville (Wallace and others, 1966)

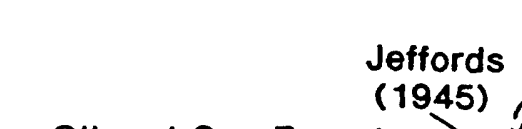

Oil and Gas Report

(Haught, 1955)

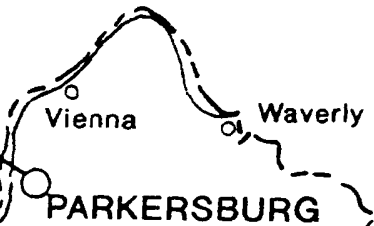
PaRKersbura

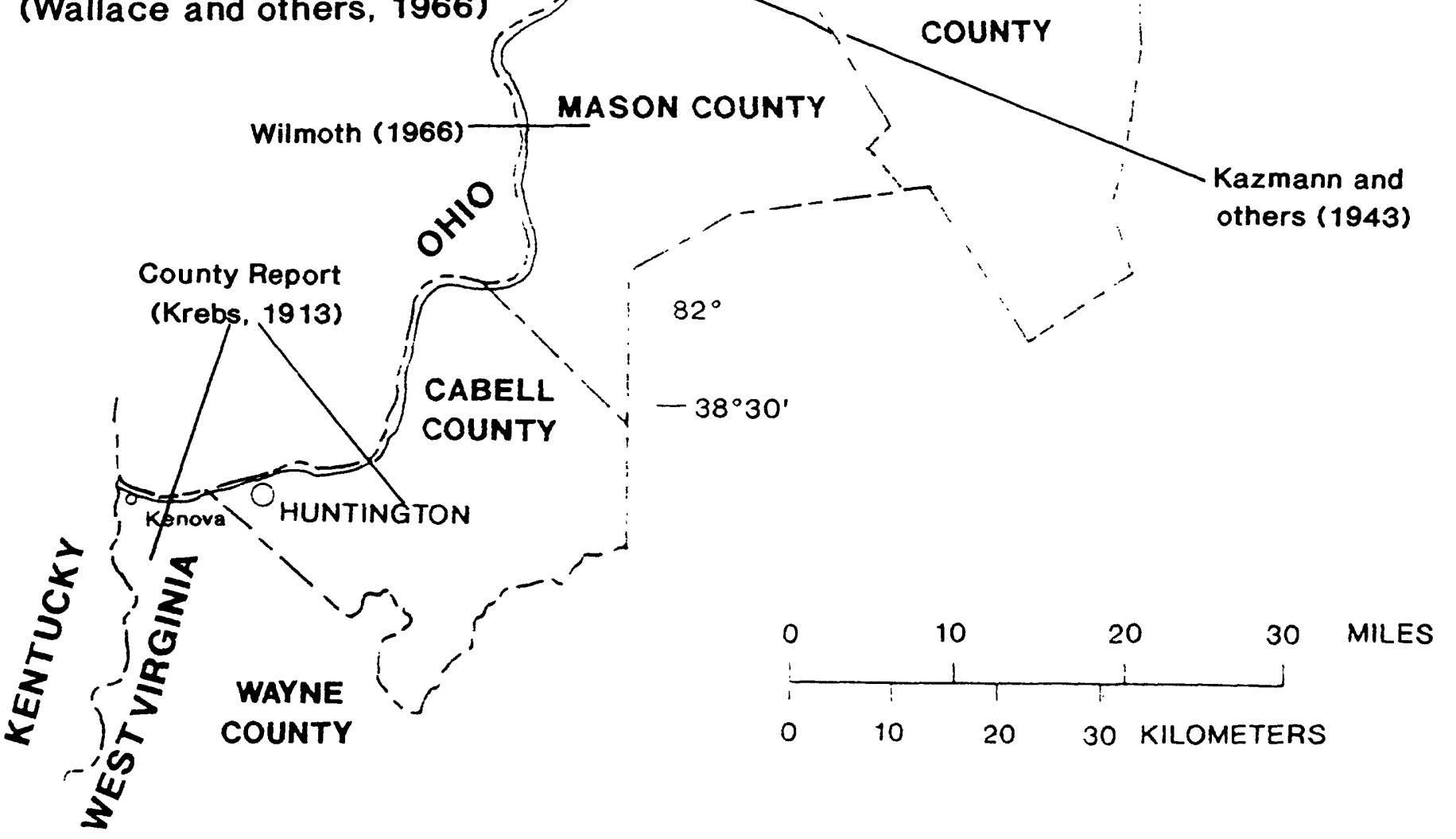




\subsection{Climate and Recharge \\ POTENTIAL FOR RECHARGE VARIES SEASONALLY}

The potential for recharge to the ground-water reservoir is greater during winter and spring.

Potential for recharge to the ground-water reservoir is greater from November through April than during the rest of the year because precipitation is significantly greater than evapotranspiration during these months. Mean monthly precipitation was at least 1 inch greater than the estimated mean monthly evapotranspiration (Munson P. E. Index, Munson, 1966) for each of these months (table 1.51). Mean monthly precipitation slightly exceeded mean monthly evapotranspiration in May and October and was less than mean monthly evapotranspiration in June, July, August, and September. A mean annual evapotranspiration of 28.70 inches was estimated using the Munson P. E. Index method described in Munson (1966). Wilmoth (1966) estimated a mean annual evapotranspiration of 25.2 inches for the Pocatalico River basin and Mason and Putnam Counties.

Table 1.5-1.--Mean monthly precipitation and evapotranspiration

\begin{tabular}{lccc}
\hline Month & $\begin{array}{c}\text { Mean monthly } \\
\text { precipitation } \\
\text { (inches) }^{a, c}\end{array}$ & $\begin{array}{c}\text { Mean monthly } \\
\text { evapotranspiration } \\
\text { (inches) }\end{array}$ & $\begin{array}{c}\text { Precipitation minus } \\
\text { evapotranspiration } \\
\text { (inches) }\end{array}$ \\
\hline January & 3.09 & 0.30 & 2.79 \\
February & 2.76 & .57 & 2.19 \\
March & 3.83 & 1.33 & 2.50 \\
April & 3.47 & 2.34 & 1.13 \\
May & 3.72 & 3.61 & 0.11 \\
June & 3.62 & 4.26 & -.64 \\
July & 4.34 & 5.07 & -.73 \\
August & 3.78 & 4.53 & -.75 \\
September & 2.95 & 3.16 & -.21 \\
October & 2.47 & 1.97 & .50 \\
November & 2.67 & 1.04 & 1.63 \\
December & 2.95 & .52 & 2.43 \\
\hline
\end{tabular}

${ }^{a}$ Modified from National Oceanic and Atmospheric Administration (1982) for period 1951-80.

${ }^{b}$ Calculated using Munson P.E. Index (Munson, 1966) for period 1951-80.

${ }^{c}$ Mean of four sites shown in figure 1.5-1.

Recharge from precipitation also varies seasonally because of variations in the form and rate of precipitation, in the condition of the ground surface, and in the density of the forest canopy. During winter and early spring, precipitation is usually less intense and more widespread; thus, it is more conducive to recharge than summer thunderstorms of greater intensity and smaller coverage which are more conducive to runoff. If there is a snow pack, melting often increases soil moisture, except when the ground is frozen. Figure 1.5-1 shows the mean monthly and mean annual precipitation for four locations. 


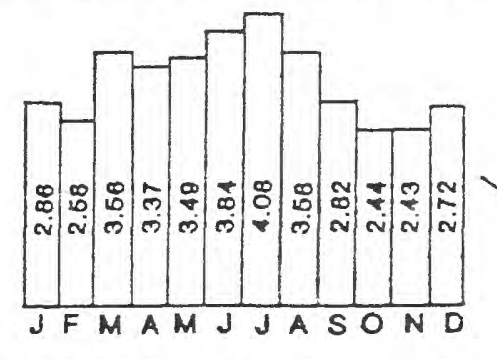

MEAN MONTHLY PRECIPITATION (1951-80), IN INCHES. AT PARKERSBURG WEATHER SERVICE OFFICE

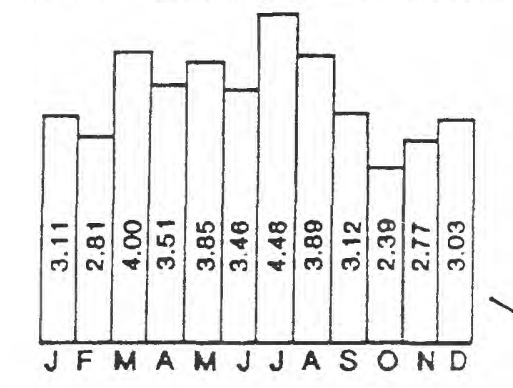

MEAN MONTHLY PRECIPITATION (1951-80), IN INCHES, AT HOGSETT GALLIPOLIS DAM
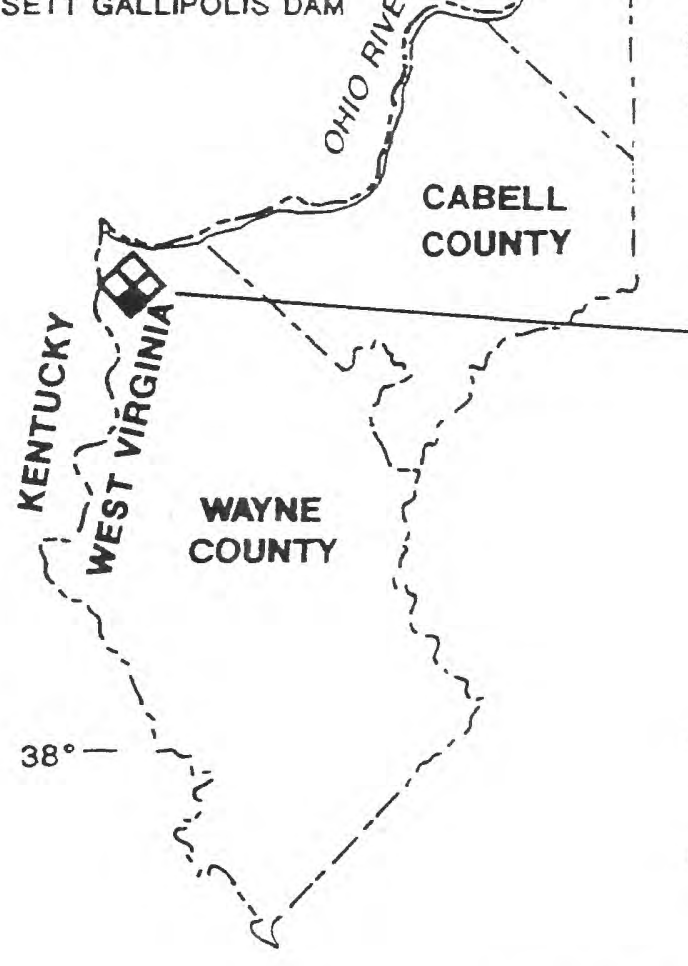

\section{EXPLANATION}

Figure 1.5-1. - - Mean monthly precipitation (1951-80). 
Forest areas reduce the water available for recharge because trees intercept precipitation before it hits the ground, and the ground covering of leaves or litter absorbs a large amount of moisture. Based on two formulas given in Chang and others (1976, p. 78), the forest canopy intercepts 13 to 22 percent of the precipitation. More precipitation is intercepted from May through October when the leaf canopy is full than from November through April. Although the Ohio River flood plain does not have a significant amount of forest area, the adjacent hills are covered mostly by deciduous and mixed forest.

\subsection{Ground-Water Use}

\section{SEVERAL BILLION GALLONS OF GROUND WATER ARE PUMPED EACH YEAR} domestic use.

Ground water in the five-county project area is withdrawn for public supply, industry, mining, and

Ground-water use in Cabell, Jackson, Mason, Wayne, and Wood Counties was at least 5.5 billion gallons in 1980 for public supply, mining, and domestic purposes, according to Stevens and Lessing (1982). This includes the entire county areas, but does not include industrial use.

About 2.1 billion gallons of ground water were withdrawn for public supply from the alluvial aquifer in 1983 . This does not include ground water pumped by the smaller facilities supplying mobile-home parks or other small communities. Figure 1.6-1 shows the location of major publicsupply wells.

One industrial facility pumped about 1.2 billion gallons during 1983 . Total maximum industrial use from known alluvial wells was estimated at 6.8 billion gallons. Thus, the total maximum ground-water pumped in 1983 from the alluvium was estimated to be about 9 billion gallons.

\subsection{GEOLOGY AND WATER-BEARING CHARACTERISTICS}

\subsection{Consolidated Sedimentary Rocks}

\section{AREA IS UNDERLAIN BY SEDIMENTARY ROCKS}

The study area is underlain by sedimentary rocks of Pennsylvanian and Permian age.

The oldest rock unit exposed in the area is the Pottsville Group of Pennsylvanian age. It occurs in small outcrops on the axis of the Burning Springs anticline in the northeast corner of Wood County (Cardwell and others, 1968 - Geologic Map of West Virginia).

The Allegheny Formation of Pennsylvanian age overlies the Pottsville Group. It crops out on the Burning Springs anticline in northern Wood County and in a deep valley in southeastern Cabell County. 



LUBECK PUBLIC SERVICE DISTRICT 


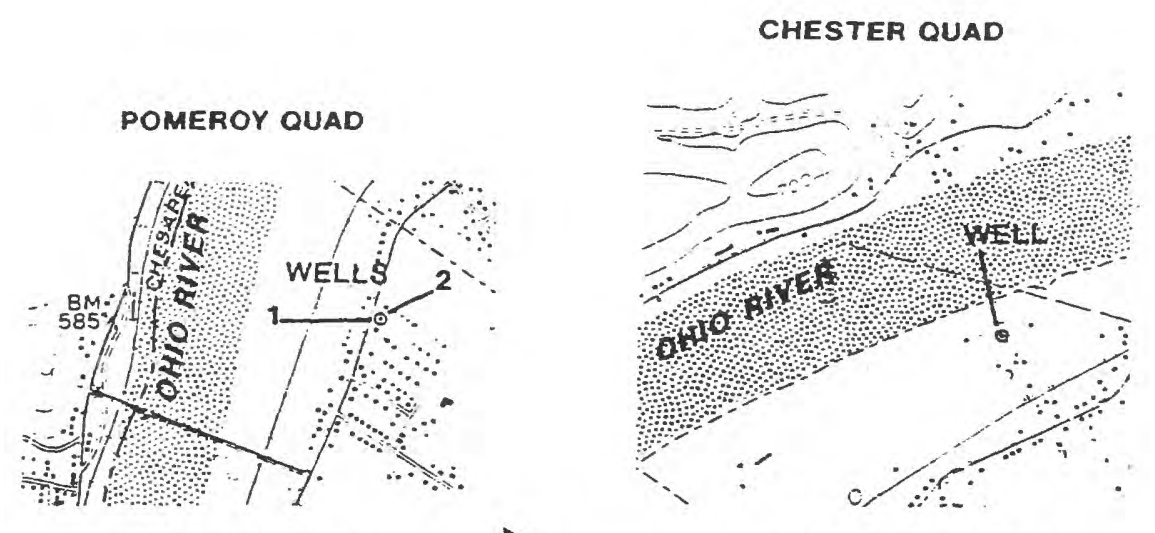

NEW HAVEN QUAD
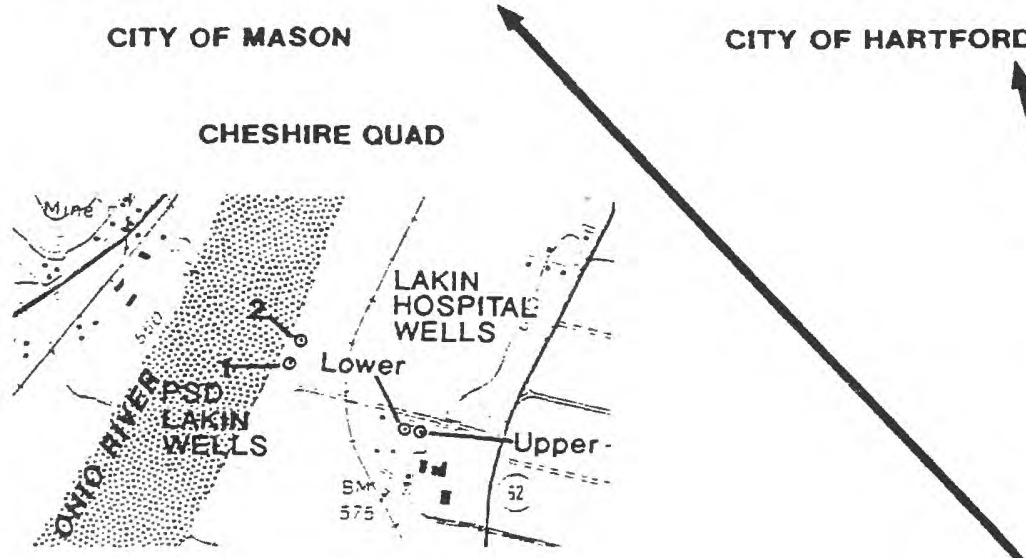
RAVENSWOOD QUAD
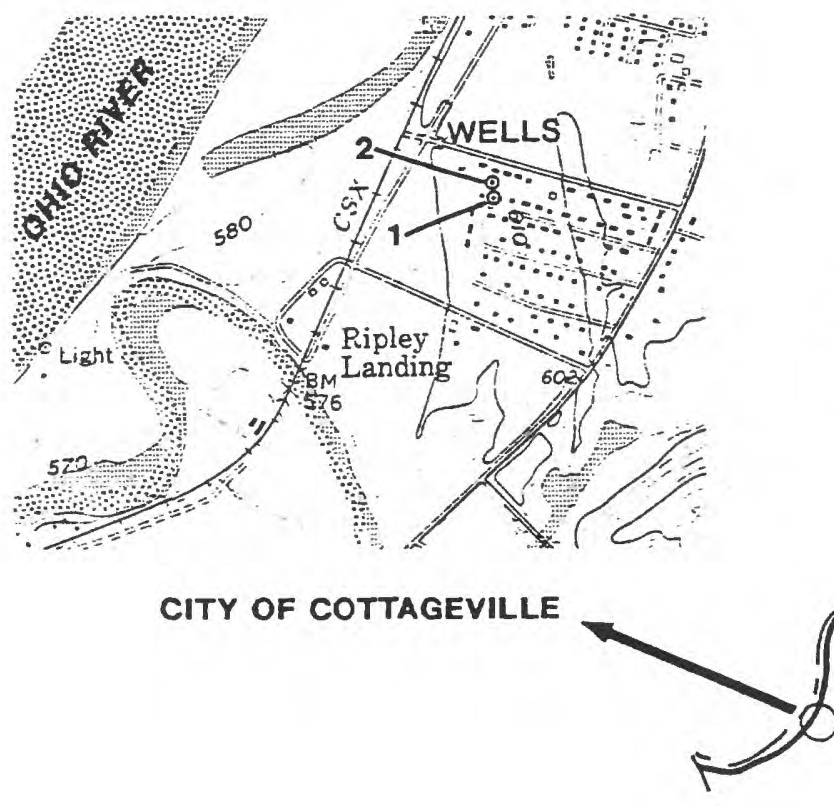

(

JACKSON

COUNTY
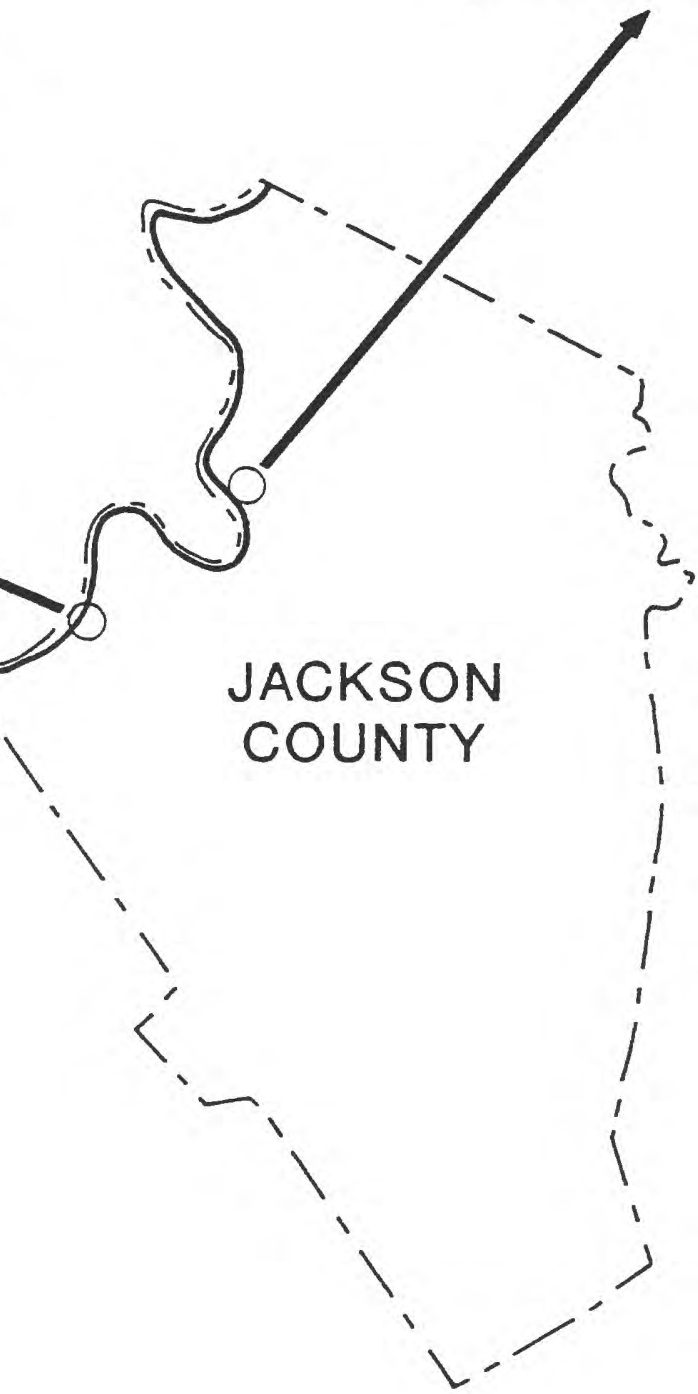

Figure 1.6-1. - - Location of public-supply wells (continued). 


\section{CATLETTSBURG QUAD}

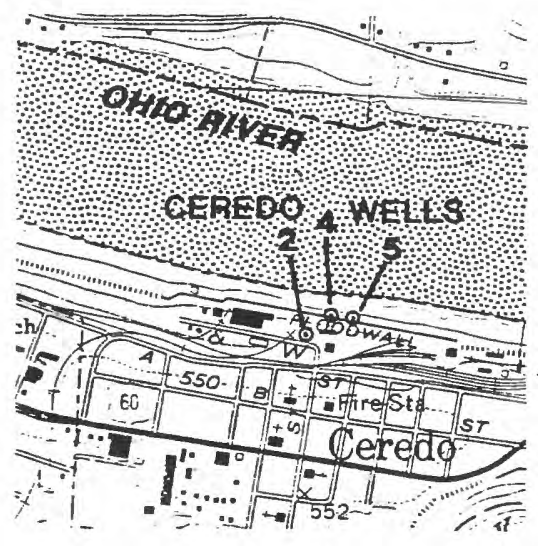

CITY OF CEREDO




The Conemaugh Group of Pennsylvanian age overlies the Allegheny Formation. It crops out on the Burning Springs anticline in northern Wood County, in a few valleys in western Mason County and northern Cabell County, and over most of southern Cabell County and northern Wayne County.

The Monongahela Group of Pennsylvanian age overlies the Conemaugh Group. It is exposed along on the flanks of the Burning Springs anticline in northern Wood County, in the eastern edge of Jackson County, in most of western and southern Mason County, and in northern Cabell County. It also is exposed on ridgetops in southern Cabell and northern Wayne Counties.

The Dunkard Group of Pennsylvanian and Permian age overlies the Monongahela Group. It forms the surface of more than half of the area and is exposed in all of Wood County except the northernmost part along the Burning Springs anticline, all of Jackson County except the eastern edge, and the eastern part of Mason County. It also forms some ridgetops in southern Mason County and northern Cabell County.

The lithology of these geologic units is described in Cardwell and others (1968). The stratigraphic nomenclature used in this report follows the usage of the West Virginia Geological and Economic Survey and does not necessarily conform to that used by the U.S. Geological Survey.

The only major geologic structure in the project area is the north-trending Burning Springs anticline in the northeastern part of Wood County. "The structural relief of this anticline is fully 1,800 feet" (Haught, 1955), bringing rocks of the Pottsville Group and Allegheny Formation to the surface along its axis. The other structural features in the project area are gentle anticlines and synclines with minor structural relief and a regional dip to the northwest (Cardwell and others, 1968).

The yield of water from wells that tap the consolidated rock units in the minor tributary basins of the Ohio River in the study area is typically low, ranging from less than 1 to as much as $80 \mathrm{gal} / \mathrm{min}$. The mean yield is about $8 \mathrm{gal} / \mathrm{min}$. The mean specific capacity ${ }^{7}$ of wells drilled in the consolidated rocks is about 0.6 ( $\mathrm{gal} / \mathrm{min}$ )/ ft of drawdown. Most of the ground water withdrawn from the consolidated sedimentary rocks is derived from secondary permeability features such as bedding-plane partings and fractures.

${ }^{1}$ Words that are in bold will appear in the "Definition of Terms" section. 
2.2 Unconsolidated Alluvial Deposits

THE ALLUVIUM, WHICH IS MORE THAN 100 FEET THICK IN SOME PLACES, PROVIDES CONSIDERABLE GROUND-WATER STORAGE

The alluvial deposits of Quaternary age are limited mostly to the flood plain of the Ohio River but contain an estimated 94 billion gallons of ground water.

The alluvium is limited mostly to the flood plain of the Ohio River and ranges in thickness from 0 feet along the hillsides to more than 100 feet in some places near the river. The lower part of the alluvial deposits consists of sand and gravel of glacial outwash origin (Deutsch and others, 1966) and is overlain in places by a layer of clay and silt of fluvial origin that can be as thick as 40 feet. The clay and silt layer contains some sand stringers. Figure 2.2-1 shows a few selected logs of the alluvium. In some areas, tributary streams have deposited a gravel delta on the alluvial deposits described above where they enter the valley of the Ohio River. The gravel deltas are in probable hydrologic continuity with the gravel in the Ohio River valley. This situation is believed to be similar to that in southwestern New York described by Crain (1966).

The amount of water in storage in the Ohio River alluvium of the project area can be estimated if certain assumptions are made. The areal extent of the alluvium is estimated to be about 69 square miles. The mean thickness of the saturated sand and gravel aquifer is estimated to be about 32 feet as determined from well logs and water-level measurements. This amounts to more than 0.4 cubic mile of saturated aquifer, or about 1,400,000 acre-feet. Specific yield is assumed to be 20.5 percent, based on the porosity and specific retention of typical sand and gravel aquifers (Heath, 1983). Consequently, the amount of water in storage in the alluvial aquifer within the project area is approximately 287,000 acre-feet, or 94 billion gallons.

The ground water in the alluvium is generally in a water-table (unconfined) condition. In some localities where the gravel is relatively thin and the overlying clay-silt layer is relatively thick, semiconfined conditions may exist. These conditions are more common at higher river stage.

\subsection{GROUND-WATER SYSTEM}

\subsection{Recharge, Movement, and Discharge}

RECHARGE TO THE ALLUVIUM IS DERIVED FROM SEVERAL SOURCES

Sources of recharge to the aquifer are infiltration of precipitation through the clay-silt layer, inflow through fractures and bedding-plane partings in the bedrock beneath and adjacent to the alluvium, inflow from tributary streams through gravel deltas, and induced inflow from the river.

Part of the precipitation that falls on the surface of the alluvium, as well as some of the overland flow from the bedrock highlands, percolates through the clay-silt layer to recharge the sand and gravel deposits of the alluvium. Although the clay-silt layer overlying the sand and gravel was originally believed to be nearly impermeable (Carlston and Graeff, 1955), water-quality data indicate that water does percolate through this layer into the more permeable sand and gravel zone. Evidence 


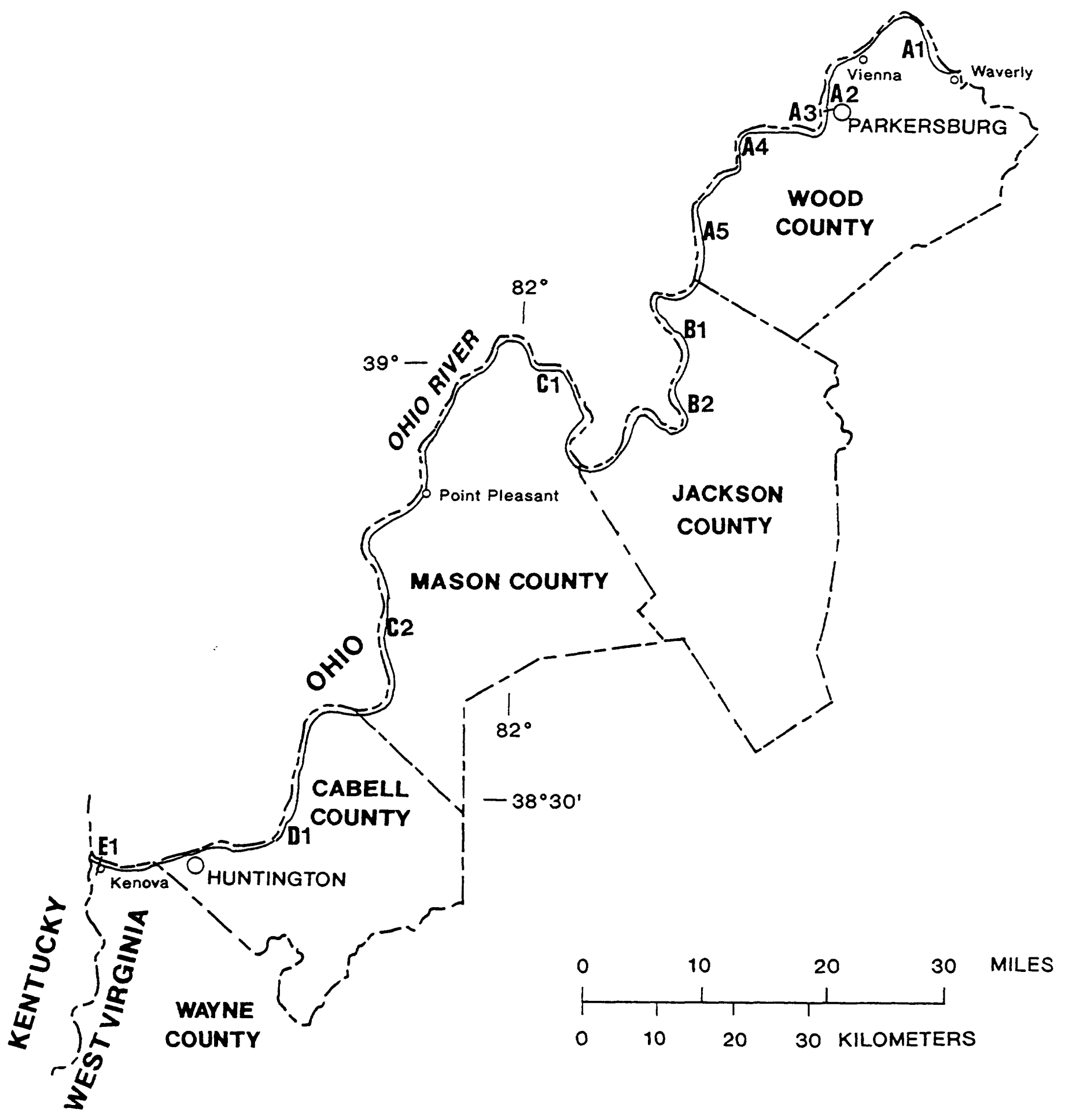

Figure 2.2-1. - - Drillers' logs of selected wells in the alluvium along the Ohio River in western West Virginia (Carlston and Graeff, 1955). 
A1



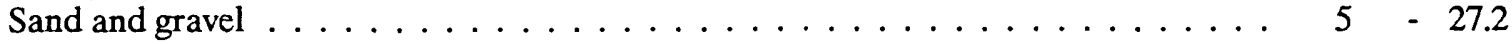

A2

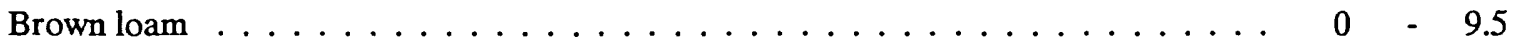

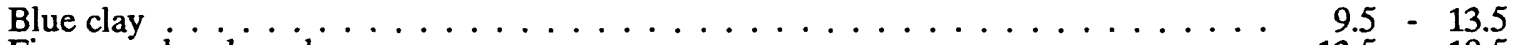

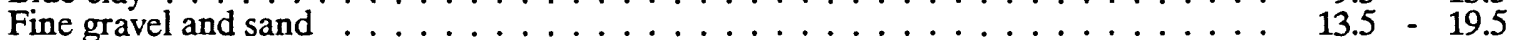

Coarse sand and fine gravel $\ldots \ldots \ldots \ldots \ldots \ldots \ldots \ldots$

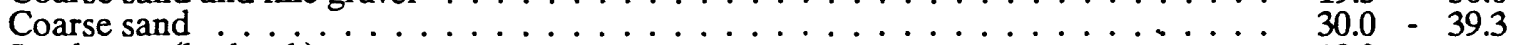

Sandstone (bedrock) $\ldots \ldots \ldots \ldots \ldots \ldots \ldots \ldots \ldots \ldots \ldots \ldots$

A3

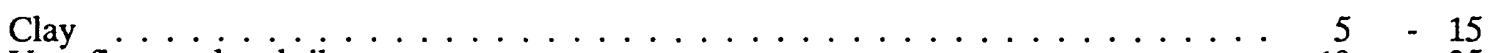



Sand and gravel . . . . . . . . . . . . . . . . . . . . . 15 . 25

A4

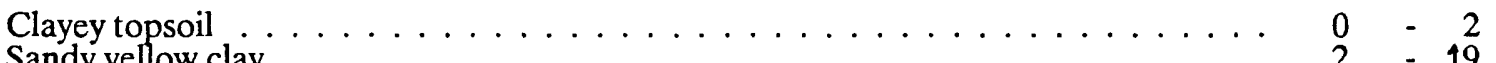

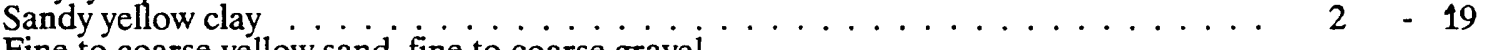

Fine to coarse yellow sand, fine to coarse gravel,

and scattered boulders $\ldots \ldots \ldots \ldots \ldots \ldots \ldots$

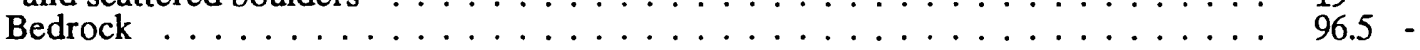

10.5

A5

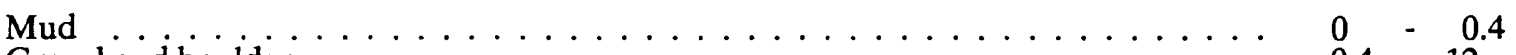

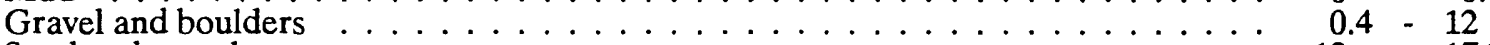

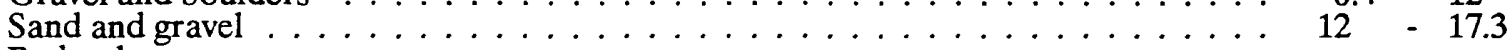

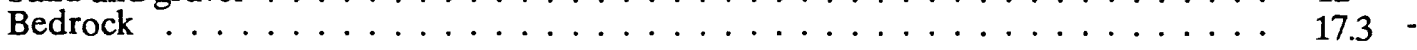

B1

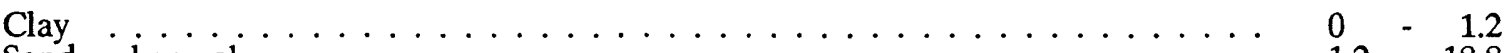

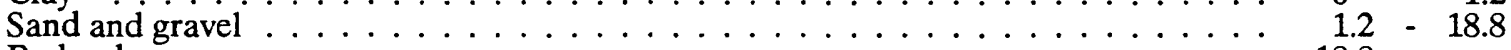




B2

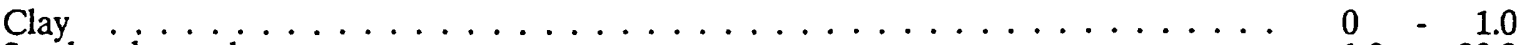

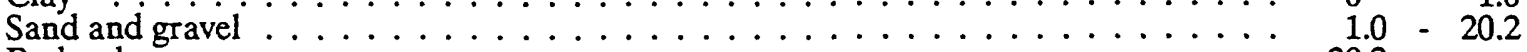

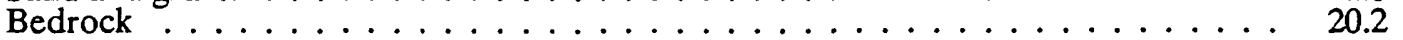

\section{C1}

Brown medium-plastic clay $\ldots \ldots \ldots \ldots \ldots \ldots \ldots \ldots \ldots \ldots \ldots \ldots \ldots \ldots$

Brown medium sand, slightly clayey $\ldots \ldots \ldots \ldots \ldots \ldots \ldots \ldots \ldots \ldots \ldots . \ldots \ldots$

Brown medium sand, slightly silty $\ldots \ldots \ldots \ldots \ldots \ldots \ldots \ldots \ldots \ldots . \ldots \ldots$

Brown sand and gravel $\ldots \ldots \ldots \ldots \ldots \ldots \ldots \ldots \ldots \ldots \ldots \ldots$

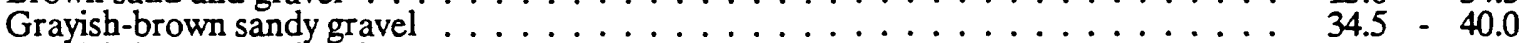

Grayish-brown sand and gravel $\ldots \ldots \ldots \ldots \ldots \ldots \ldots \ldots \ldots \ldots \ldots \ldots \ldots \ldots$

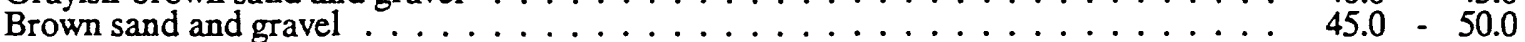

Brownish-gray medium sand $\ldots \ldots \ldots \ldots \ldots \ldots \ldots \ldots \ldots . \ldots \ldots \ldots$



\section{C2}

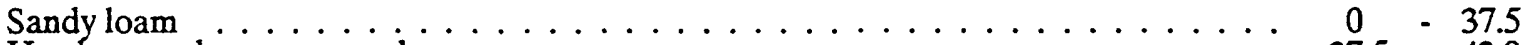

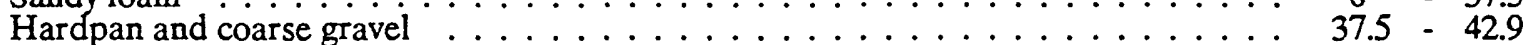

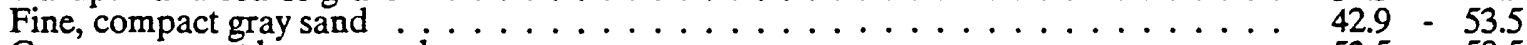

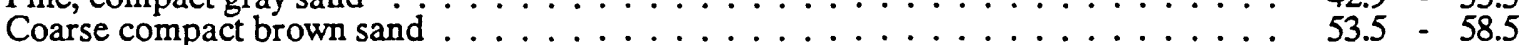

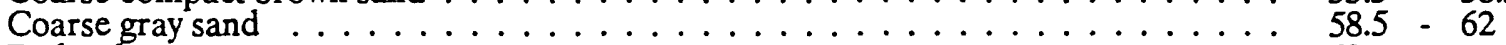

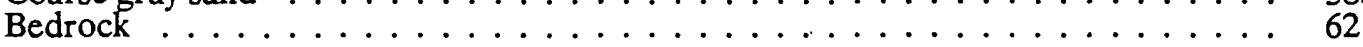

D1

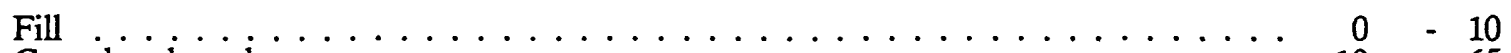

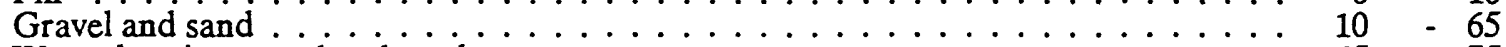

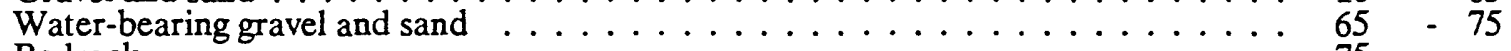

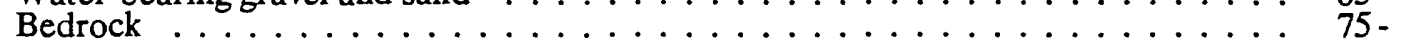

E1

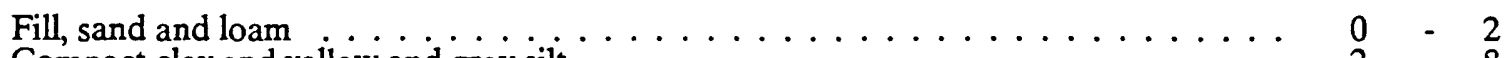

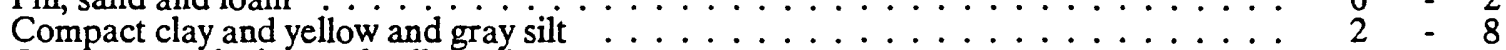

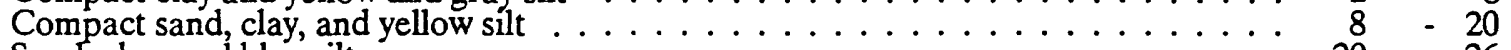

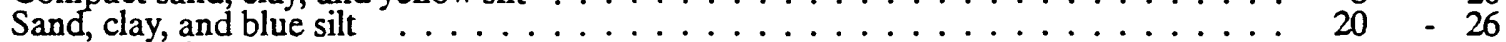

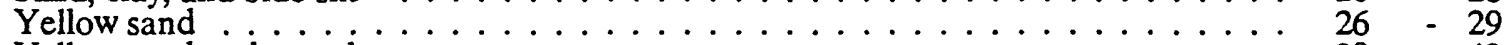

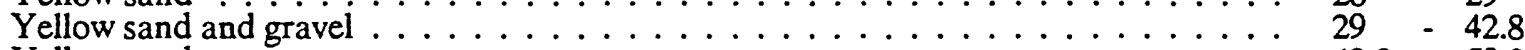

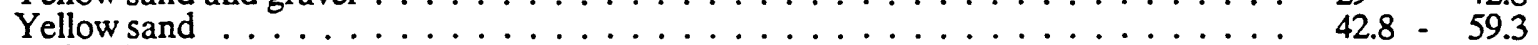

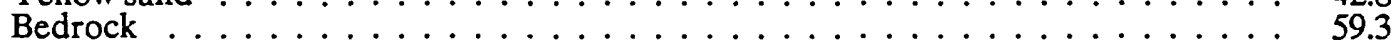

Figure 2.2-1. - - Drillers' logs ... (continued). 
of percolation through the clay-silt layer is indicated by the abnormally high concentration of nitrate in the ground water beneath or near areas containing feedlots or where fertilizers have been applied. This indicates that nitrate has been leached from these sources (see page 39). As shown by the drillers' logs in figure 2.2-1 (preceding section), the clay-silt layer is not uniform in thickness and composition; thus, the amount and rate of percolation are variable. Water levels at two wells near Point Pleasant indicate that both the alluvium and bedrock aquifers are recharged by precipitation (fig. 3.1-1). The water levels in both wells show rises that began in December 1978 and July 1980 after periods of heavy precipitation. Ground-water levels rose for a 4-month period after the heavy precipitation of December 1978. The gradual and extended character of this rise could have been caused by the slow percolation of water to the aquifers and by frozen precipitation and ground, although snowfall was not excessively high nor air temperature excessively low during this period.

The alluvium can also be recharged by water flowing from the adjacent bedrock at the edge of the alluvial flood plain and from bedrock underlying the alluvium. Flow of water from the bedrock to the alluvium could occur through fractures located near anticlines (Clark and others, 1976), through bedding-plane partings located beneath tributary valleys, and through vertical fractures along valley walls adjacent to the alluvial flood plain (Wyrick and Borchers, 1981). Figure 3.1-1 shows that the bedrock receives recharge before the alluvium after periods of heavy precipitation. The water level in the bedrock well started to rise several days before the water level in the alluvial well. This suggests the possibilities that percolation of water through the clay-silt layer to the alluvium is relatively slow and that the bedrock provides recharge to the alluvium.

Tributary streams flowing onto the alluvium from the hills have deposited gravel deltas at the edge of the Ohio River valley. Water flowing from these streams can percolate through the deltas to the gravel under the clay-silt layer. This phenomenon has been described by Crain (1966) in western New York State. Discharge in Little Grave Creek at Moundsville, north of the project area, decreased from an estimated $10 \mathrm{ft}^{3} / \mathrm{s}$ in the upstream bedrock area to an estimated $0.5 \mathrm{ft}^{3} / \mathrm{s}, 1.25$ mi downstream on the alluvial flood plain (Friel, E.A., U.S. Geological Survey, oral commun., 1984). Thus, Little Grave Creek appears to be providing considerable recharge to the alluvium.

Man's activities can change the natural ground-water flow pattern and thus affect recharge. Recharge to the alluvium from the Ohio River may occur when the aquifer close to the river is pumped heavily and the ground-water level is drawn below the river level. This recharge is limited to the alluvial area between the river and pumped well. Recharge could also occur during periods of high river stage. Rises in the alluvial water level occurring in February and March 1979 and March and April 1980 suggest that the river might be providing some recharge to the alluvium. However, under natural conditions the water level in the aquifer is above the river in most places most of the time. Furthermore, the permeability of the streambed probably is quite low. In describing conditions in the Scioto River valley in Ohio, Norris and Fidler $(1969$, p. 45) state: "The vertical permeability of the streambed sediments is thus only about one-thirteenth as high as the vertical permeability measured across the full thickness of the aquifer. A layer of silt, mud, and organic debris, possibly having penetrated no more than a few inches into the underlying sediments, is thought to be chiefly responsible for the relatively low permeability of the streambed." The same conditions have been observed on the Ohio River and probably limit recharge to the alluvium from the river. 

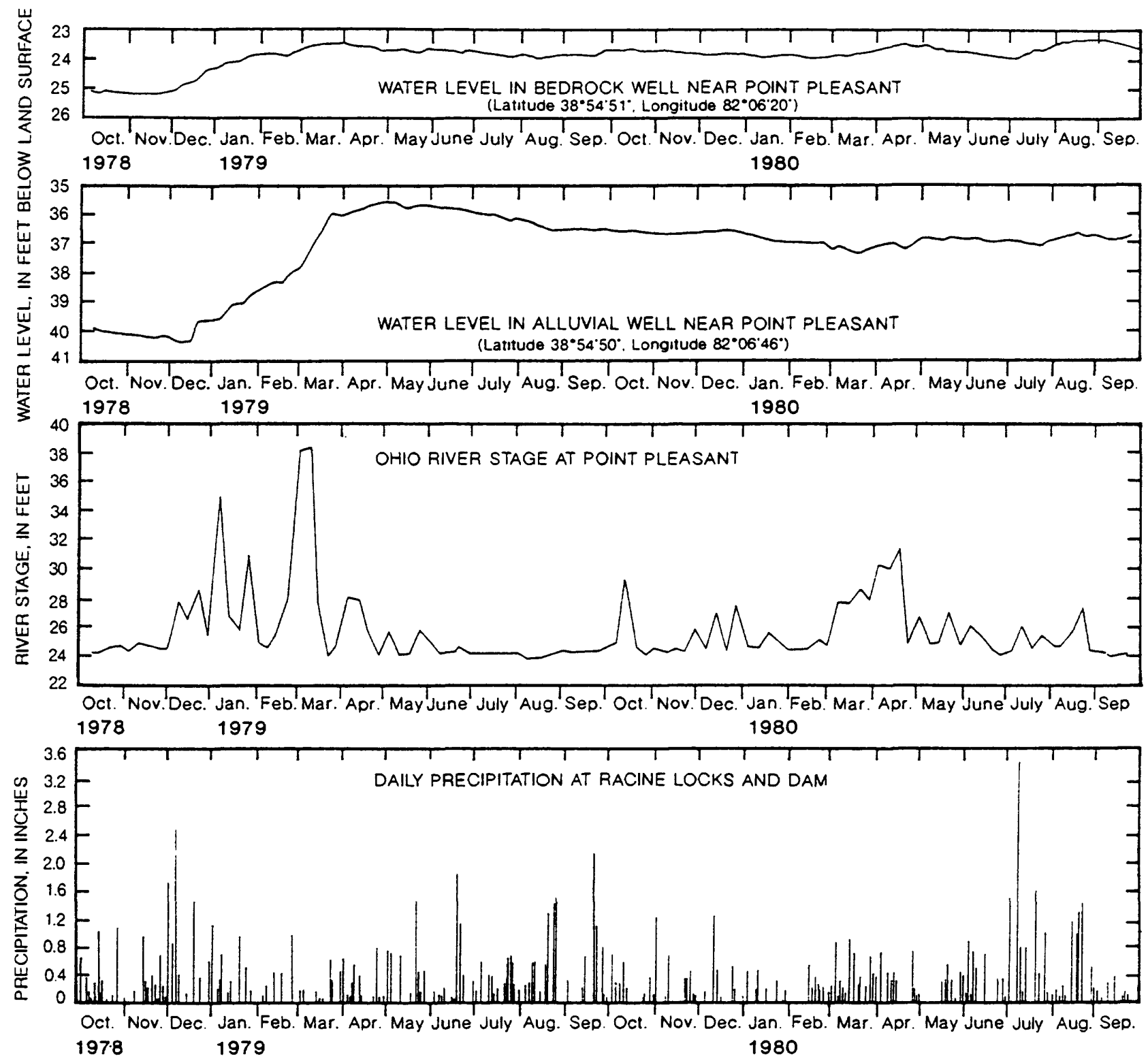

Figure 3.1-1. - - Ground-water levels and river stage near Point Pleasant, October 1978 to September 1980. 
Discharge from the alluvium occurs at the riverbed and riverbank from both the saturated and unsaturated zones. Ground water from the saturated zone of the alluvium, which is comprised mostly of sand and gravel, enters the river through its bed. Discharge from the unsaturated zone occurs at the riverbank where water emerges from the thin sand layers in the upper clayey part of the alluvium. The water in that part of the unit can flow horizontally along the sand layers more easily than vertically through the clay and silt layers.

\subsection{Hydraulic Characteristics of Alluvial Aquifer \\ SPECIFIC CAPACITY, SATURATED THICKNESS, TRANSMISSIVITY, AND HYDRAULIC CONDUCTIVITY WERE DETERMINED FOR THE OHIO RIVER ALLUVIUM}

The alluvium has the following hydraulic characteristics: Mean specific capacity--31 gallons per minute per foot of drawdown, mean saturated thickness of aquifer--32 feet, mean transmissivity-4,200 feet squared per day, and mean hydraulic conductivity--140 feet per day.

Specific capacity of 52 wells ranged from 12 to $102(\mathrm{gal} / \mathrm{min}) / \mathrm{ft}$ with a mean of 31 $(\mathrm{gal} / \mathrm{min}) / \mathrm{ft}$ and a median of $25(\mathrm{gal} / \mathrm{min}) / \mathrm{ft}$ (fig. 3.2-1). Specific capacities include measurements made over a period of several decades and were obtained from well-site inventories, drillers' records, earlier studies, and consultants' reports. The specific capacities were determined for varying conditions of river stage, well efficiency, direction of ground-water movement, and water-table and semiconfined aquifer conditions. Drawdown for a given yield increases as well screens become partially clogged, and thus well efficiency decreases with time. Induced infiltration from the Ohio River decreases drawdown and increases specific capacity. Some alluvial wells are capable of yielding several hundred gallons of water per minute. Yields of more than one thousand gallons per minute have been reported. Yields of 69 alluvial wells ranged from 6 to $1,300 \mathrm{gal} / \mathrm{min}$ with a mean of 283 $\mathrm{gal} / \mathrm{min}$ and a median of $250 \mathrm{gal} / \mathrm{min}$.

The saturated thickness of the alluvium ranged from 10 to 50 feet, with a mean of 32 feet and a median of 33 feet (fig. 3.2-2). These values were obtained during various river stages which directly affect the water level and thus the saturated thickness. The construction of locks and dams and the consequent raising of the river pools behind these dams has increased the saturated thickness of the alluvium. Saturated thickness was determined by subtracting the depth to the static water level from the depth to bedrock. The effect of confinement on static water levels was assumed to be minimal for the purpose of estimating saturated thickness. 


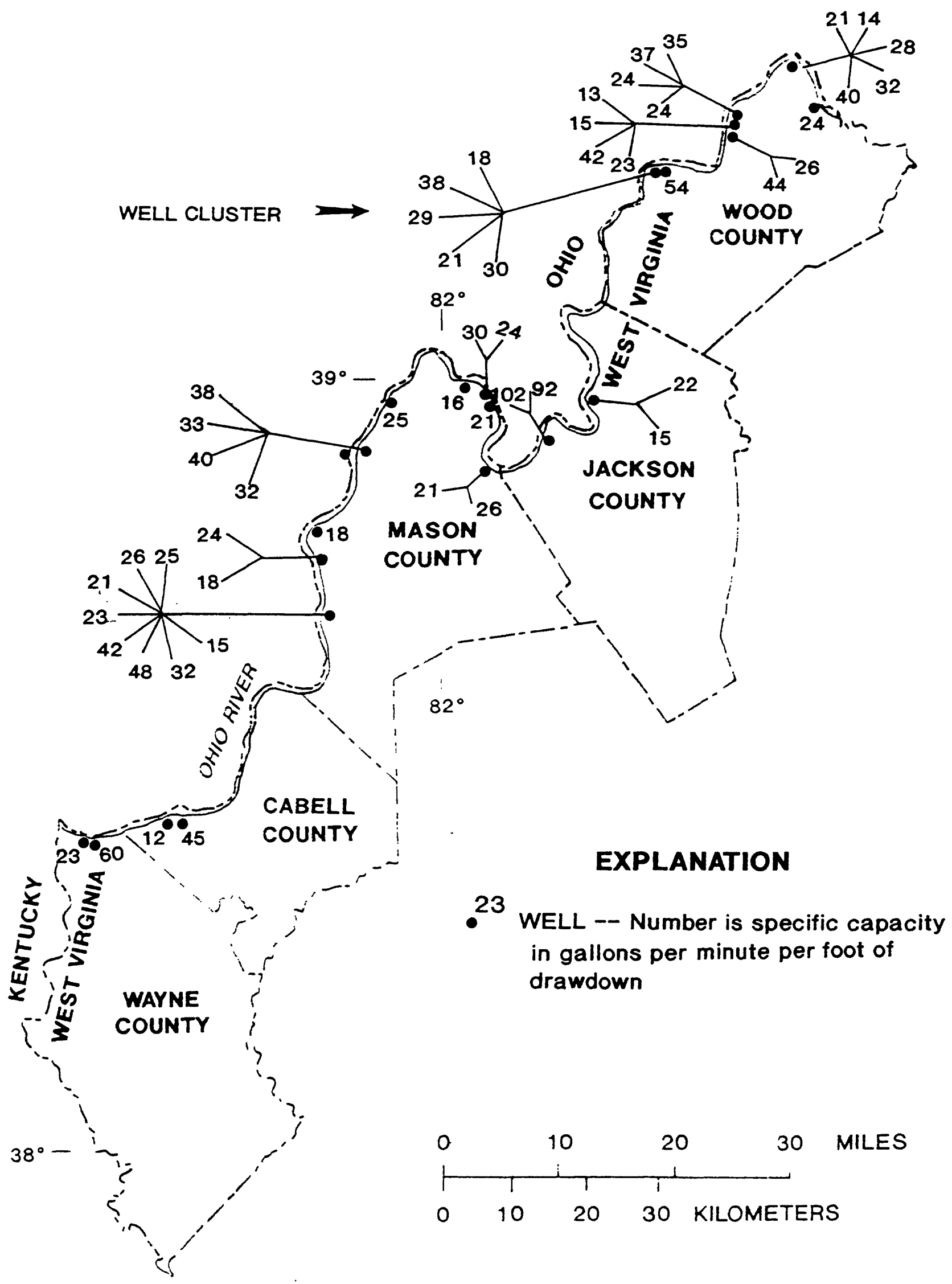

Figure 3.2-1. - - Specific capacity. 


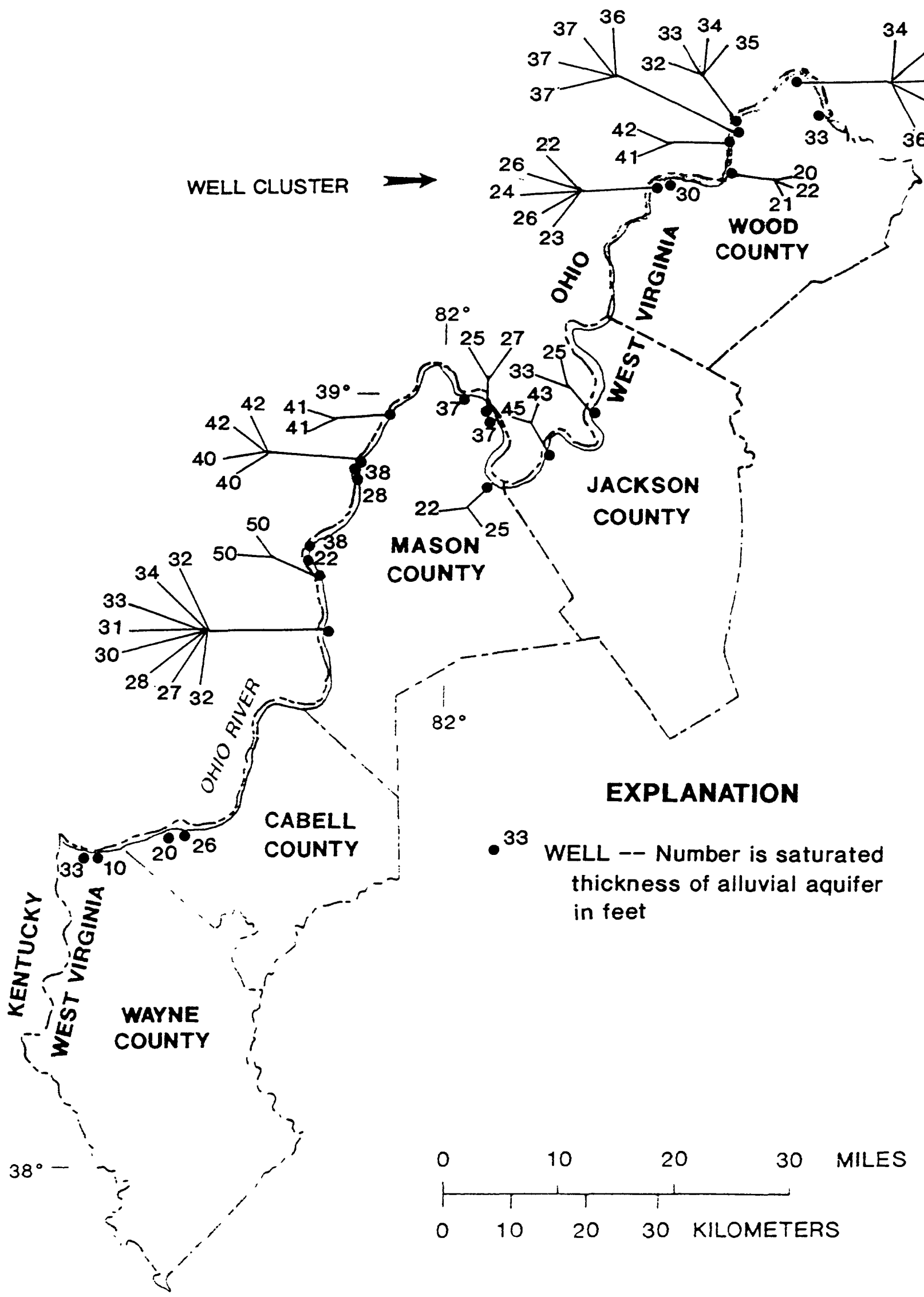

Figure 3.2-2. - - Saturated thickness of aquifer. 
Estimated transmissivities ranged from 1,500 to $16,000 \mathrm{ft}^{2} / \mathrm{d}$ with a mean of $4,200 \mathrm{ft}^{2} / \mathrm{d}$ and a median of $3,700 \mathrm{ft}^{2} / \mathrm{d}$ (fig. 3.2-3). Transmissivity gives an indication of the rate of movement of ground water. Transmissivities were estimated from the specific capacities of 31 alluvial wells with pumping tests of known duration using the following equation developed by Theis (Bentall, 1963):

where:

$$
\mathrm{T}^{\prime}=\mathrm{C}(1+0.3)(1,300-264 \log 105 S+264 \log t)
$$

$\mathrm{T}^{\prime}$ is an intermediate value of transmissivity,

$C$ is the specific capacity of the pumped well,

$S$ is the aquifer storage coefficient, and

$t$ is the time, in days, that the well was pumped.

The estimated transmissivity is determined graphically from " $\mathrm{T}$ " and " $\mathrm{C}$ ". To simplify calculations, well diameter was assumed to be $1 \mathrm{foot}$, and storage coefficient was assumed to be 0.2 . Several transmissivities reported in previous studies were much higher than those estimated in this report. Reasons for the higher reported transmissivities are (1) pumping tests of insufficient duration, (2) storage coefficients less than 0.2 in some areas, and (3) induced infiltration to the alluvium from the Ohio River.

Hydraulic conductivity was computed for 31 wells by dividing the estimated transmissivity by the saturated thickness. The hydraulic conductivity ranged from 40 to $680 \mathrm{ft} / \mathrm{d}$ with a mean of $140 \mathrm{ft} / \mathrm{d}$ and a median of $110 \mathrm{ft} / \mathrm{d}$ (fig. 3.2-4). The hydraulic conductivity can be used to compute the specific discharge if the hydraulic gradient is known. Ground-water movement is in the direction of the hydraulic gradient. Under natural conditions, the hydraulic gradient dips gently from the hills to the Ohio River. Withdrawal of large quantities of water from wells close to the Ohio River can reverse this gradient between the pumped wells and the river. The direction and slope of the hydraulic gradient is affected close to lock and dam sites where river pools of different elevations meet abruptly. Sources of recharge such as ponds, lakes, and streams on the alluvial flood plain also affect the hydraulic gradient.

All aquifer characteristics calculated in this report are variable with time and geographical location and should be used with discretion. 


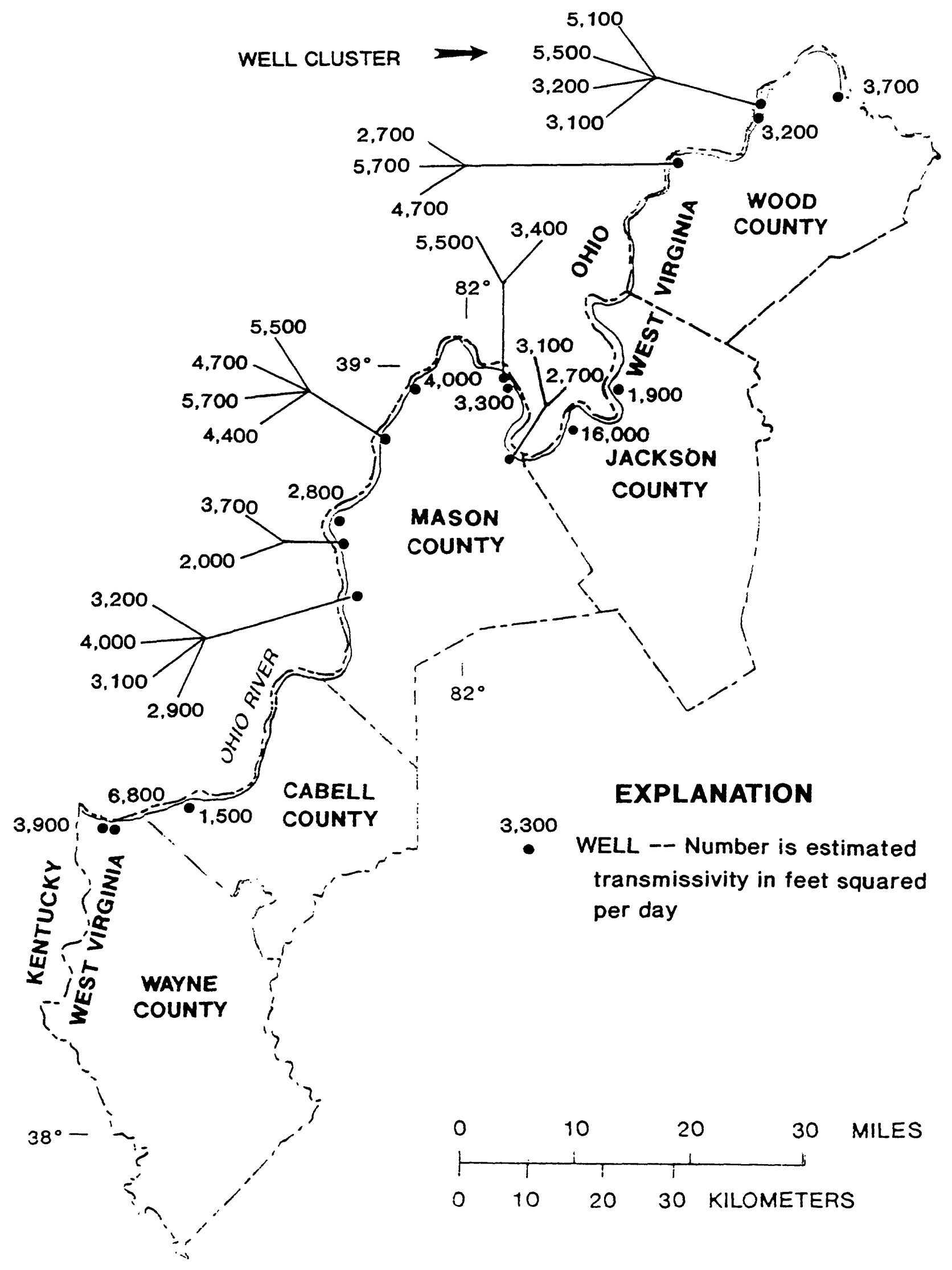

Figure 3.2-3. - - Estimated transmissivity. 


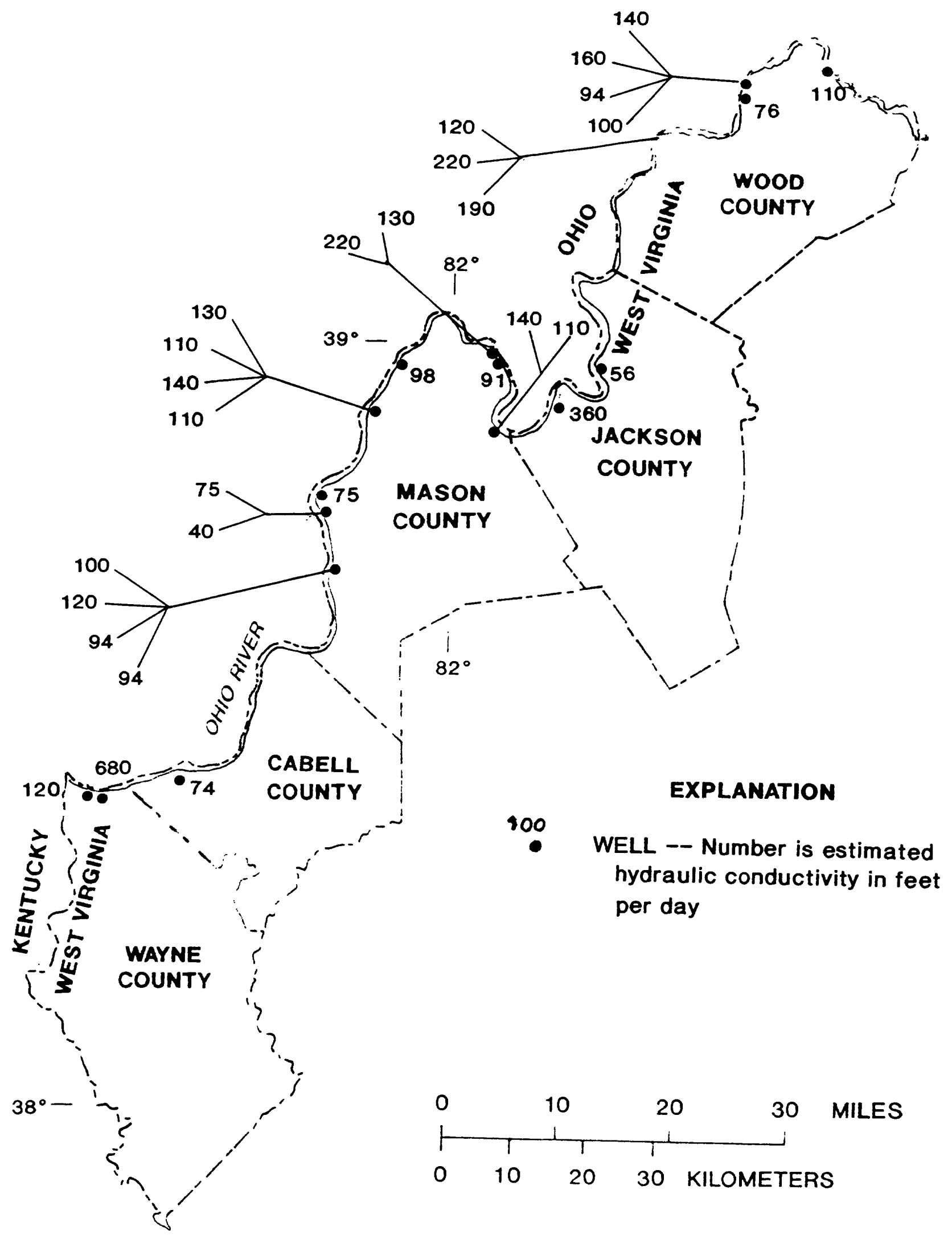




\title{
4.0 WATER QUALITY
}

\subsection{Data Collection}

\author{
GROUND-WATER SAMPLES FROM MORE THAN \\ FORTY WELLS WERE ANALYZED
}

\begin{abstract}
Water samples from alluvial wells, bedrock wells on or near the alluvial flood plain, and radial collectors were analyzed.
\end{abstract}

More than 40 ground-water samples were analyzed during the study. Samples were collected from wells drilled into alluvium, wells drilled through the alluvium and into the underlying bedrock, and from radial collectors with laterals extending into the alluvium and under the Ohio River. Analyses included all major cations and anions, several metals, phenols, and dissolved organic carbon. Several additional samples from bedrock wells near the alluvial flood plain were collected during a previous study (Shultz, 1984) and are incorporated into this report. These wells were sampled for major cations and anions and common metals. The location of sampled wells is shown on figures 4.21, 4.3.1-1, 4.3.2-1, 4.3.2-2, 4.3.3-1, 4.3.4-1, and 4.3.5-1 . Alluvial wells are designated with an " $\mathrm{A}^{\text {", }}$ bedrock wells with a "B", and radial collectors with an " $R$ ". The data collected as part of this study are in U.S. Geological Survey files.

\subsection{Water Type}

\section{CALCIUM BICARBONATE WAS THE MOST COMMON WATER TYPE}

Calcium bicarbonate was the predominant water type in 53 percent of the well samples.

Water type was determined for well samples collected during the study (fig. 4.2-1). Water type is based on predominant cations and anions. Calcium bicarbonate was the most common water type, accounting for 53 percent of the samples. Sodium bicarbonate was the second most common type, comprising 19 percent of the samples. Calcium sulfate accounted for 3 percent of the samples. All but one of the remaining samples had either calcium or bicarbonate as a predominant ion with various combinations of sodium, magnesium, sulfate, and chloride.

Calcium was the predominant cation in 68 percent of the samples. Sodium was the second most common cation and was predominant in 20 percent of the samples. The remaining samples were various mixtures of calcium, sodium, and magnesium, with no single cation predominating.

Bicarbonate was the predominant anion in 81 percent of the samples. Sulfate was predominant in 3 percent of the samples. The remaining samples were various mixtures of bicarbonate, sulfate, and chloride, with no single anion predominating. 
EXPLANATION
A $\bigcirc$ Alluvial well
B $\bigcirc$ Bedrock well
R O Radial Collector

PREDOMINANT CATIONS

$\theta$ Calcium

$\theta$ Sodium

No predominant cation

(greater than fifty percent)

PREDOMINANT ANIONS

$\oplus$ Bicarbonate
$\oplus$ Sulfate
No predominant anion
(greater than fifty percent)

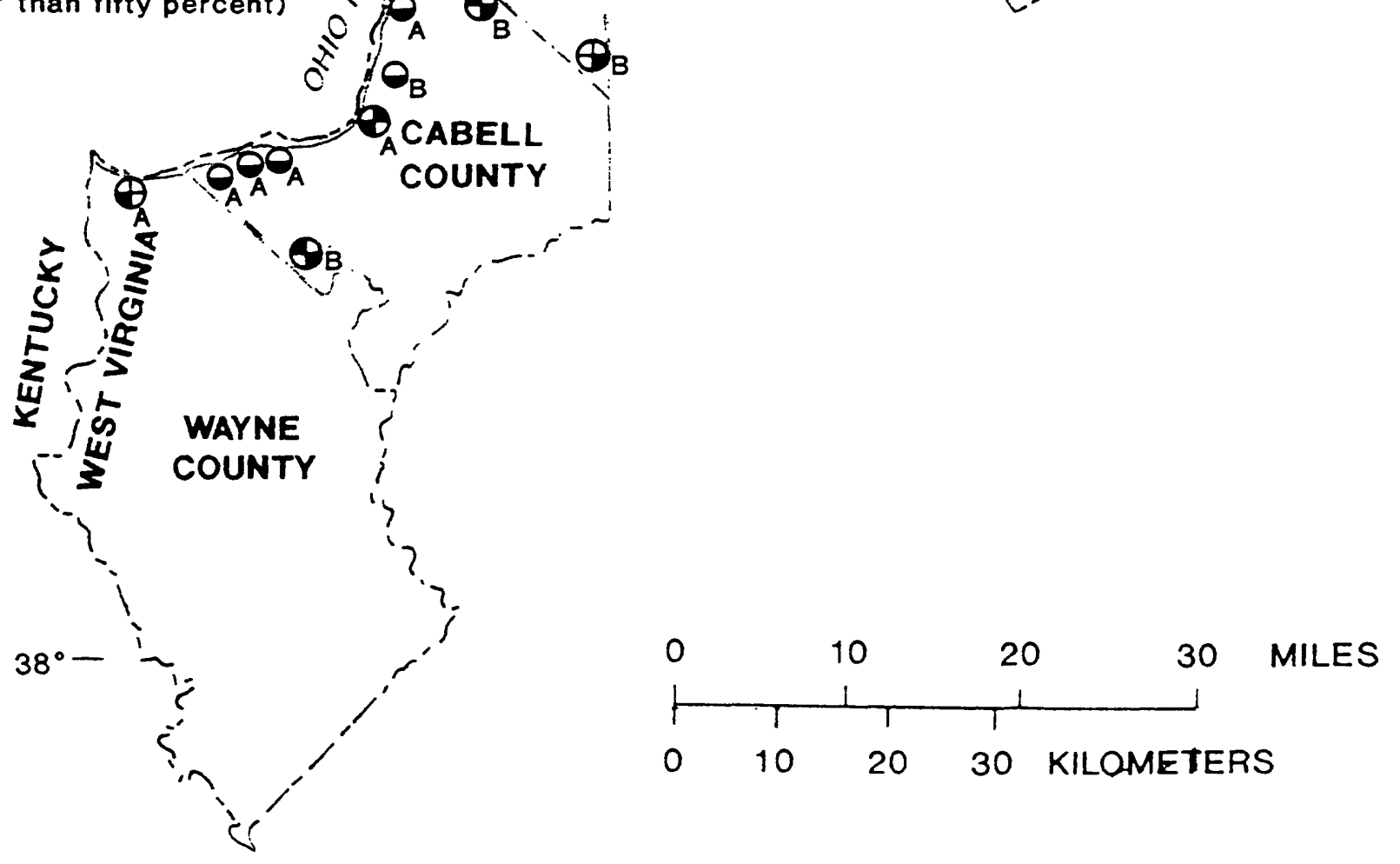

Figure 4.2-1. - - Areal distribution of cations and anions. 


\subsection{Chemical Constituents}

4.3.1 Saltwater

\section{SALTWATER IS NOT A PROBLEM AT THE PRESENT TIME}

Sodium chloride was not the predominant water type in any of the sampled wells, although saltwater underlies all of the area at varying depth.

Sodium chloride was not the predominant constituent in any of the sampled wells. Increasing chloride concentration may be the first indication of salt-water contamination. The West Virginia State Board of Health (1981) recommends a limit of $250 \mathrm{mg} / \mathrm{L}$ of chloride for drinking water. Figure 4.3.1-1 shows the areal distribution of chloride concentration in ground water. Only one well, a deep bedrock well on the alluvial flood plain in Jackson County, exceeded the $250 \mathrm{mg} / \mathrm{L}$ limit for chloride. Chloride concentration for all wells ranged from 2.6 to $330 \mathrm{mg} / \mathrm{L}$ with a mean of $37 \mathrm{mg} / \mathrm{L}$ and a median of $22 \mathrm{mg} / \mathrm{L}$.

Saltwater underlies all of the area at depths ranging from land surface to about 300 feet (Foster, 1980). The term "saltwater" is used in this report to describe ground water with objectionable concentrations of sodium chloride or other salts. Foster (1980) shows locations where saltwater is within 100 feet of the land surface. Heavy pumping of wells in these locations could cause saltwater contamination of the fresh ground water. Factors affecting the depth to saltwater include geology, topography, ground-water circulation, and human activities.

The depth to saltwater is shallower on the alluvial flood plain and in valleys than on hillsides or hilltops. Fewer well owners report saltwater contamination on hillsides and hilltops than in valleys. This can be explained by the relation between the fresh ground water and the underlying saltwater and by the circulation of water from areas of recharge to areas of discharge (fig. 4.3.1-2).

Ground-water circulation in a drainage basin is from recharge areas in the hills to discharge areas in the valleys. The mean altitude of the water table is much higher under the hills, and saltwater is found at greater depth there than elsewhere in the basin. Some of the water percolating downward in the recharge area penetrates deeply enough to become part of the flow system involving the underlying saltwater.

In the discharge areas of the basin, deeper water is moving toward the surface. This water has mixed with the saltwater underlying the region and may be under greater hydraulic head than the overlying freshwater. Therefore, the saltwater moves upward to the surface when it reaches a fracture or well.

Man can also influence the depth to saltwater. Heavy pumping from the overlying freshwater zone can cause upward migration of the saltwater in areas where saltwater is at shallow depth. Saltwater in oil and gas reservoirs is frequently under sufficient head to flow upward through wells. When deep wells are uncased or improperly cased, contamination of upper freshwater zones may occur (Bain and Friel, 1972). Oil and gas fields are present in all five counties of the study area (Patchen, 1982). 


\section{EXPLANATION}
A $\bigcirc$ Alluvial well
B $\bigcirc$ Bedrock well
R $\bigcirc$ Radial Collector

DISSOLVED CHLORIDE, IN

MILLIGRAMS PER LITER

$00-25$

Q26-50

O 51-250

- $>250$
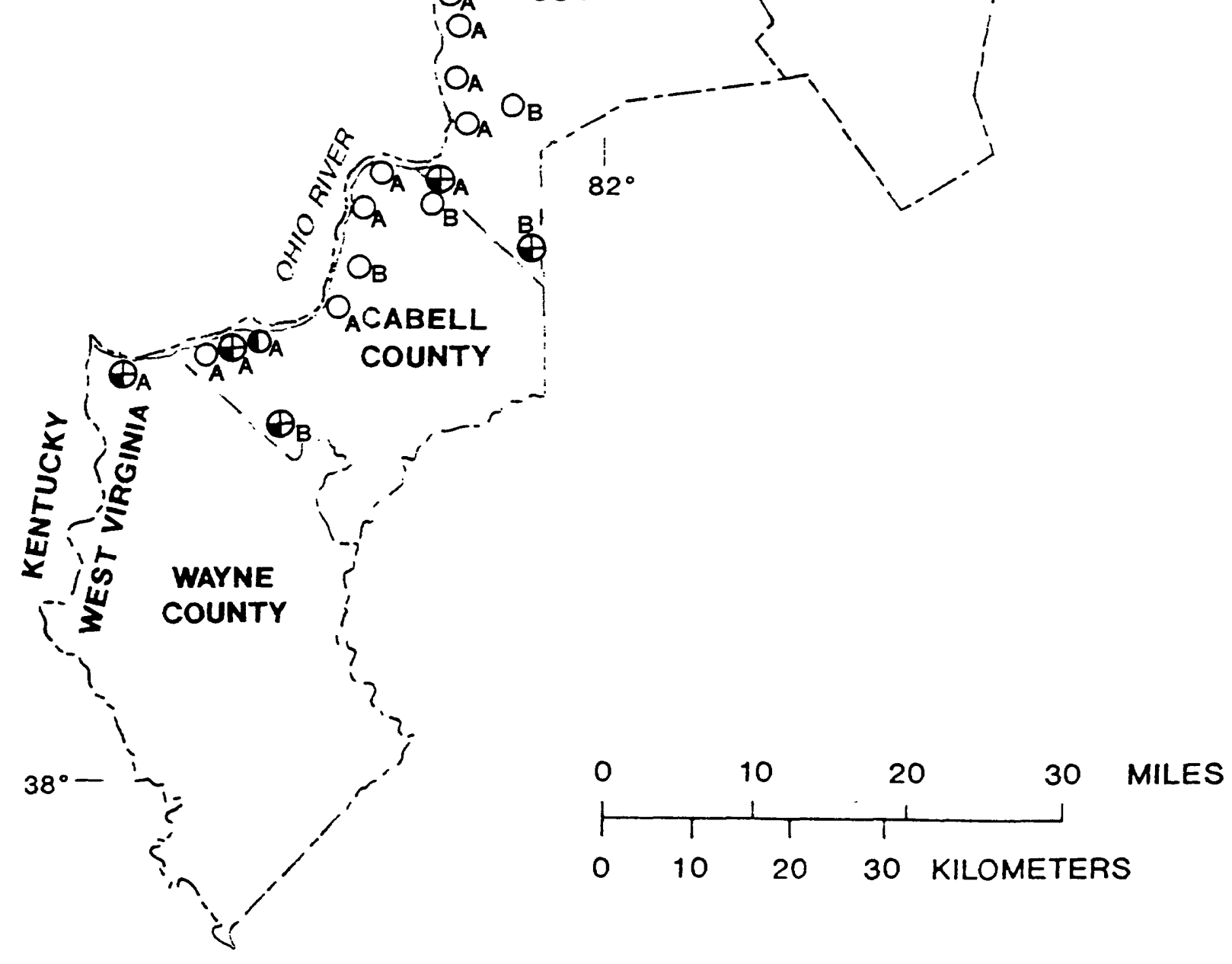

Figure 4.3.1-1. - - Areal distribution of dissolved chloride. 


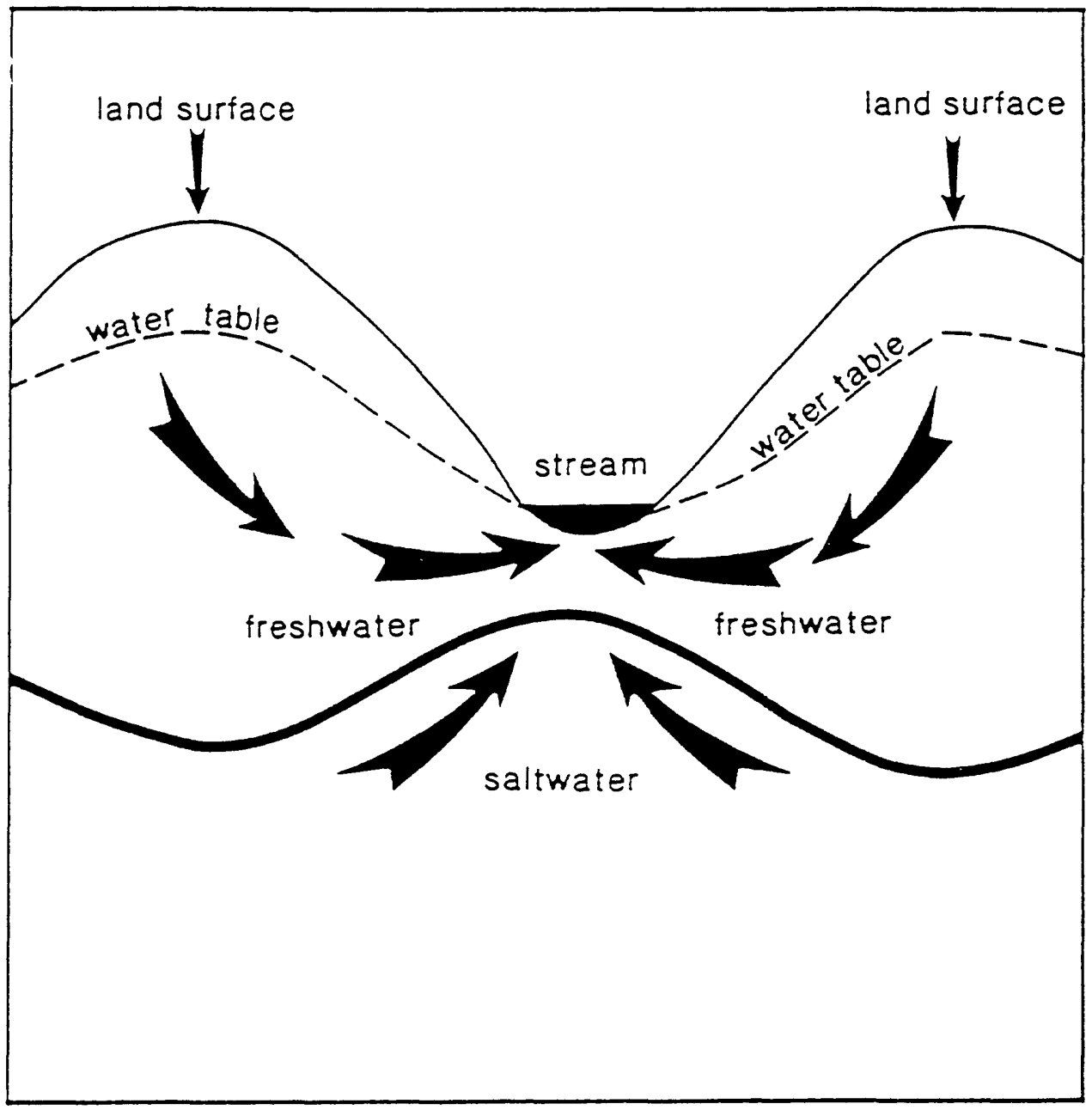

NOT TO SCALE

EXPLANATION

— DIRECTION OF GROUND-WATER FLOW

Figure 4.3.1-2. -- Relation between freshwater and saltwater. 


\title{
IRON AND MANGANESE POSE A PROBLEM \\ FOR GROUND-WATER USE
}

\begin{abstract}
Iron and manganese concentrations exceeded State drinking-water limits in many alluvial wells along the Ohio River.
\end{abstract}

Dissolved iron exceeded the $300 \mu \mathrm{g} / \mathrm{L}$ limit for drinking water (West Virginia State Board of Health, 1981) in 10 of 34 alluvial wells, and dissolved manganese exceeded the $50 \mu \mathrm{g} / \mathrm{L}$ limit for drinking water in 17 of 34 alluvial wells (figs. 4.3.2-1 and 4.3.2-2). Elevated iron and manganese concentrations in drinking water are not serious health hazards, but can cause problems in wells, distribution systems, food processing, and industrial processes.

Elevated iron and manganese concentrations in ground water can cause precipitates to form on well screens and in distribution lines. Iron and manganese can be removed from ground water after it has been withdrawn from a well. Thus, distribution lines usually can be protected from such precipitates, whereas well screens are more difficult to protect. Precipitates of iron and manganese and calcium carbonate clog screens and thus decrease well efficiency. As well efficiency decreases, increased drawdown can lower the water level below the top of the screen. Oxygen brought into contact with the screen further accelerates precipitation. Clogged well screens necessitate expensive cleaning or even the need for new wells (Jeffords, 1945).

The concentration of dissolved iron in ground water from both alluvial and bedrock wells ranged from less than 3 to $13,000 \mu \mathrm{g} / \mathrm{L}$. The concentration of dissolved manganese ranged from less than 1 to $3,100 \mu \mathrm{g} / \mathrm{L}$. Iron and manganese concentrations were not significantly different in ground water from alluvial wells than in ground water from bedrock wells. The median iron concentration was $16 \mu \mathrm{g} / \mathrm{L}$ in alluvial wells and $25 \mu \mathrm{g} / \mathrm{L}$ in bedrock wells. Likewise, median manganese concentration was $54 \mu \mathrm{g} / \mathrm{L}$ in alluvial wells and $34 \mu \mathrm{g} / \mathrm{L}$ in bedrock wells.

Ground water from some alluvial wells contained a higher concentration of manganese than iron. Hem (1970) states that ground water containing a higher concentration of manganese than iron is uncommon, but is present in wells along the Ohio River in West Virginia.

\subsubsection{Hardness}

\section{HARD WATER IS A COMMON PROBLEM}

\section{Hard ground water is found throughout the area and clogs well screens and distribution lines.}

Hard water is a common problem throughout the area and is independent of the topographic location of the well or the geologic unit tapped. Hard water can cause well screens and distribution lines to become clogged with iron, manganese, and calcium carbonate precipitates. Seventy-eight percent of the ground-water samples had a hardness concentration greater than $120 \mathrm{mg} / \mathrm{L}$. Concentrations ranged from 5 to $530 \mathrm{mg} / \mathrm{L}$, and the mean was $200 \mathrm{mg} / \mathrm{L}$. Figure 4.3.3-1 shows the areal distribution of hardness. Hardness is classified by the U.S. Geological Survey (Durfor and Becker, 1964) based on the following ranges of equivalent calcium carbonate concentration in 
EXPLANATION

A $\bigcirc$ Alluvial well

B $\bigcirc$ Bedrock well

R $\bigcirc$ Radial Collector

DISSOLVED IRON, IN

MICROGRAMS PER LITER

$0-100$

$\oplus$ 101-200

( 201-300

$>300$
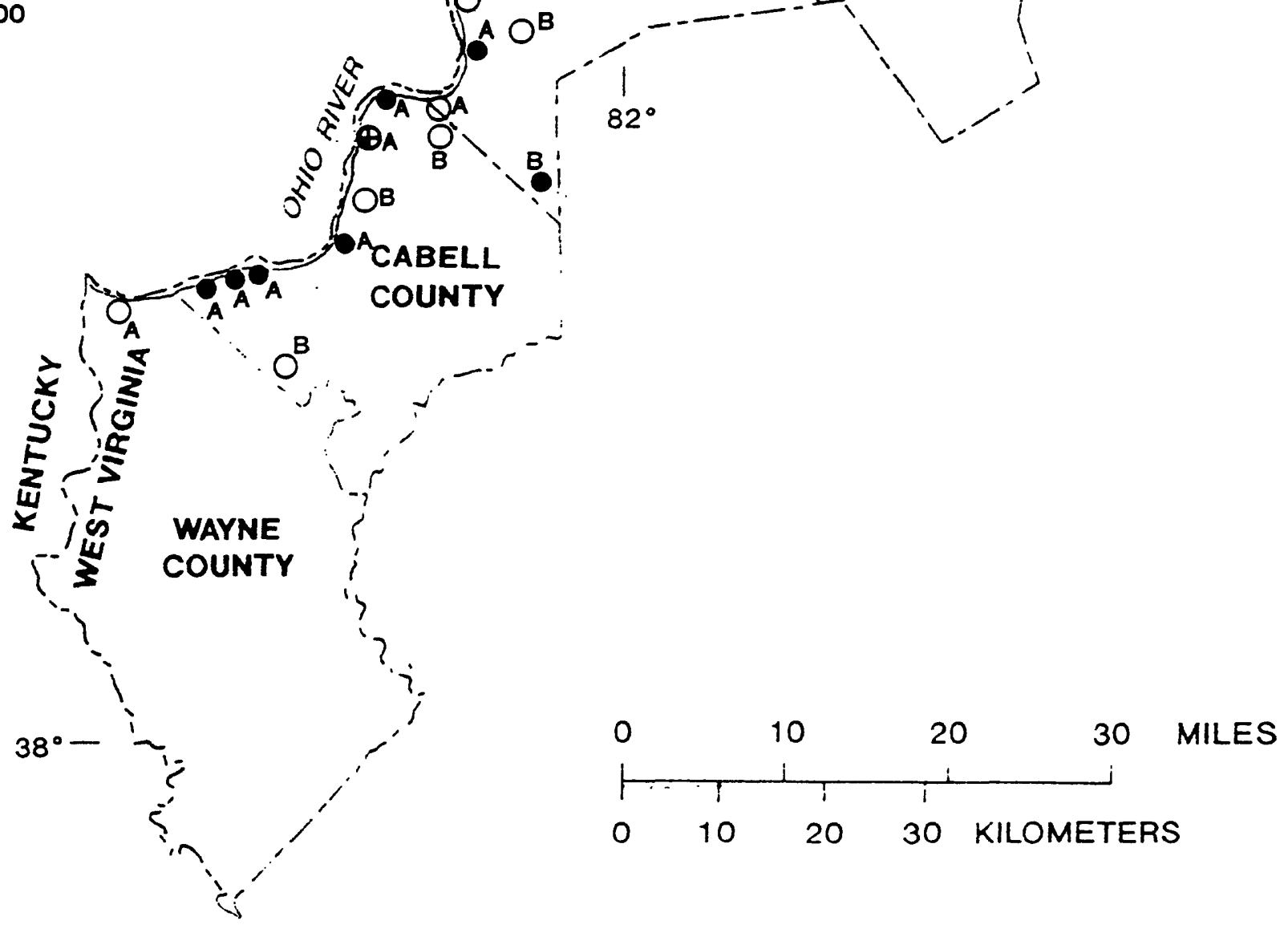

Figure 4.3.2-1. . - Areal distribution of dissolved iron. 
EXPLANATION

A $\bigcirc$ Alluvial well

B $\bigcirc$ Bedrock well

R $\bigcirc$ Radial Collector

DISSOLVED MANGANESE. IN

MICROGRAMS PER LITER
$0-10$
Q11-25
D 26-50
$>50$

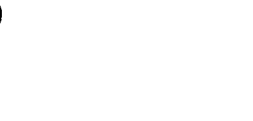

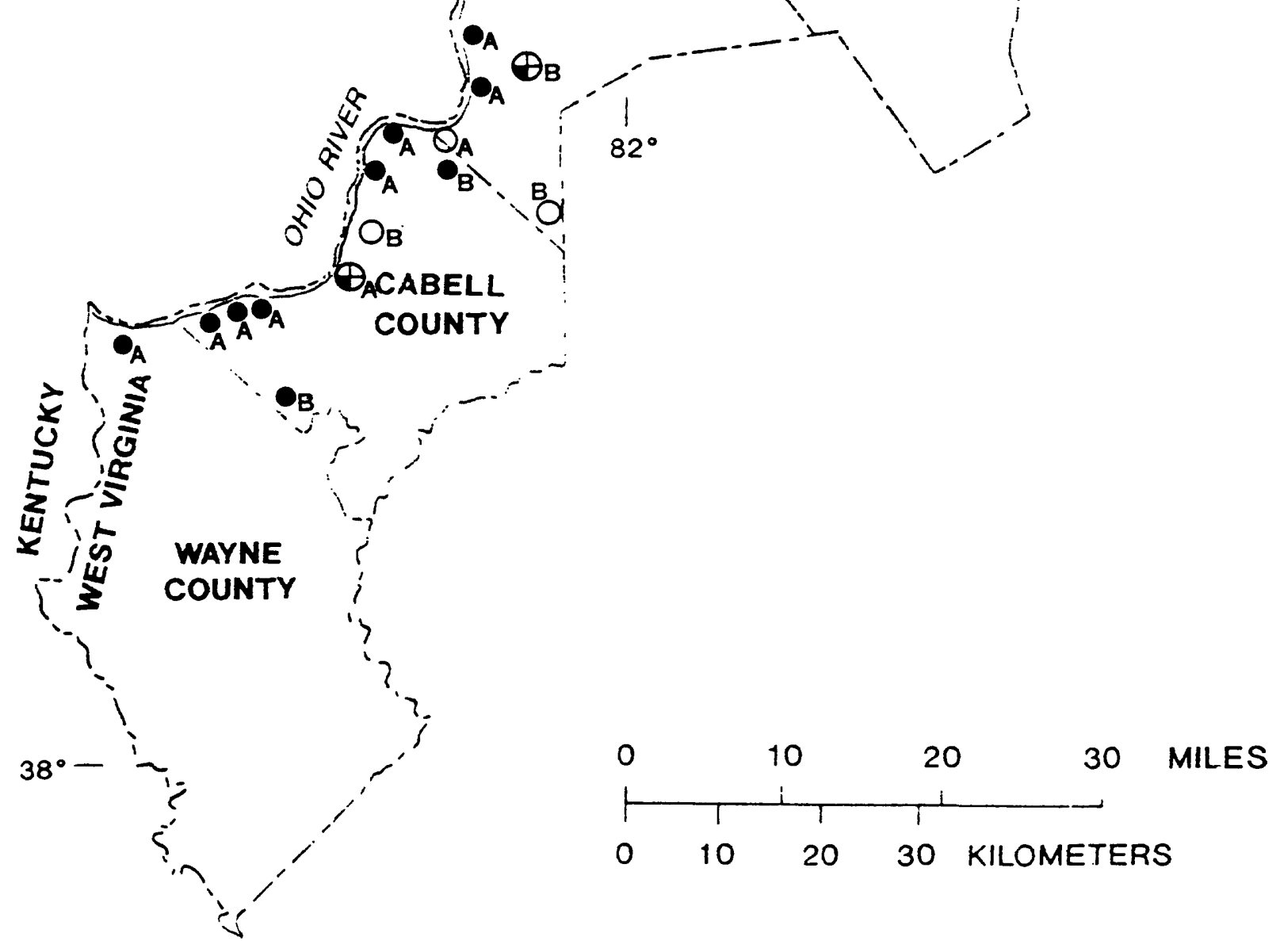

Figure 4.3.2-2. - - Areal distribution of dissolved manganese. 


\section{EXPLANATION}
A $\bigcirc$ Alluvial well
B $\bigcirc$ Bedrock well
R $\bigcirc$ Radial Collector

HARDNESS, IN MILLIGRAMS PER

LITER OF CALCIUM CARBONATE
$0-60$
Ө61-120
D 121-180
- $>180$
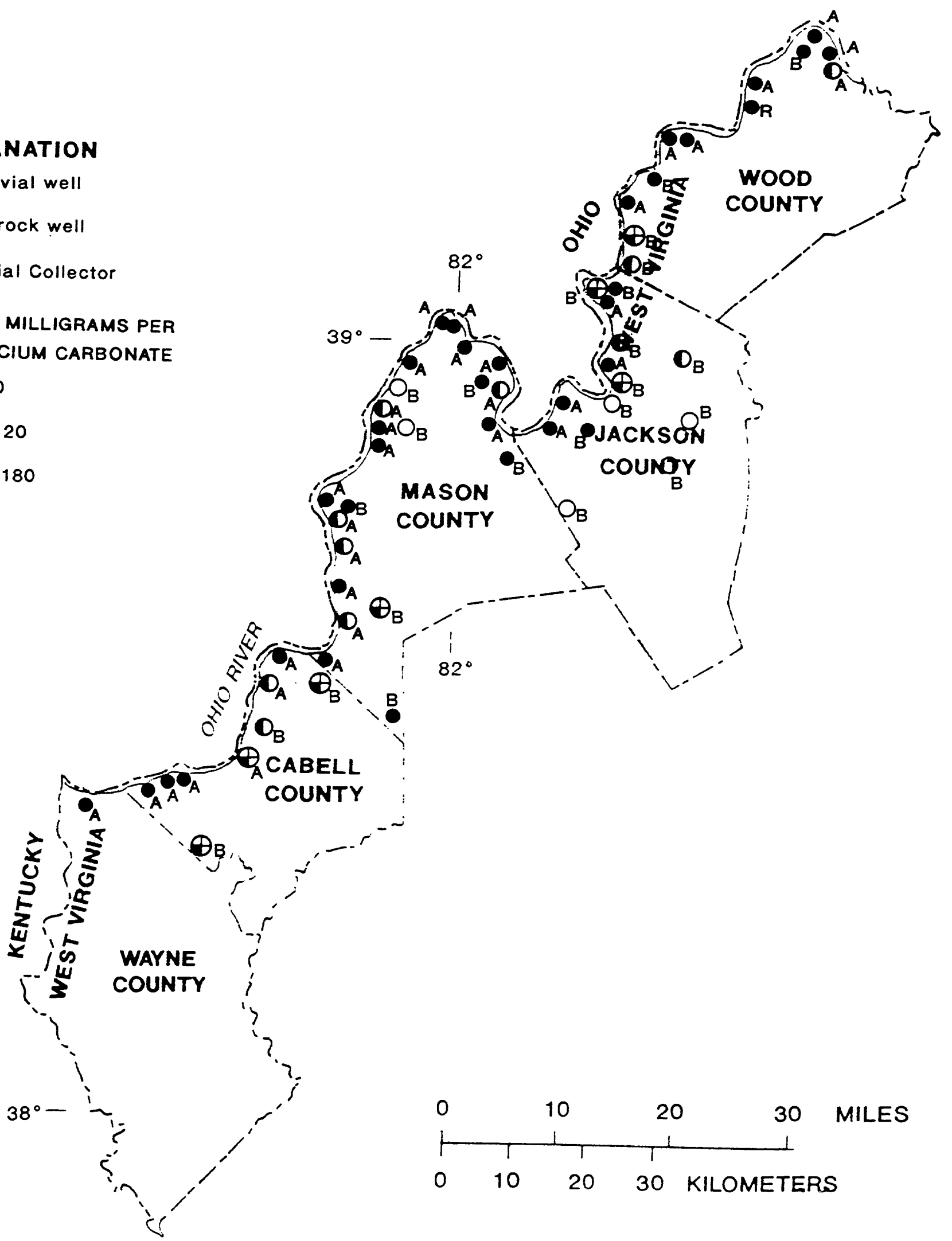

Figure 4.3.3-1. - - Areal distribution of hardness. 
milligrams per liter: 0 to 60 is soft, 61 to 120 is moderately hard, 121 to 180 is hard, and greater than 180 is very hard. Calculations were based on the summation of calcium, magnesium, strontium, iron, aluminum, zinc, manganese, and barium concentrations (American Public Health Association, Inc., 1960 , p. 132).

Calcium ions comprised an average of 76 percent of the hardness of each sample, and magnesium ions comprised 23 percent. Together they comprised more than 90 percent of the hardness in every sample.

The major source of calcium and magnesium ions probably is limestone. Lithologic analyses of the Ohio River alluvium (Carlston and Graeff, 1955) contain limestone pebbles. Chemically, limestone is classified as a carbonate rock, and pure limestone consists of calcium carbonate. Limestone in this area is of freshwater origin and generally is impure. It contains variable amounts of magnesium carbonate, iron carbonate, iron oxide, phosphate, silicon dioxide, and aluminum oxide (McCue and others, 1939).

\subsubsection{Sulfate}

\section{SULFATE IS NOT A PROBLEM IN ALLUVIAL GROUND WATER}

\section{Waverly.}

High sulfate concentration is not encountered in ground water from alluvial wells from Kenova to

None of the alluvial wells sampled in the reach of the Ohio River alluvium from Kenova to Waverly (western area of West Virginia) had sulfate concentration that exceeded the $250 \mathrm{mg} / \mathrm{L}$ limit of sulfate for public-drinking water (West Virginia State Board of Health, 1981). This is in contrast to the reach of the Ohio River alluvium from Waverly to Chester (northern area of West Virginia), for which ground water from five wells, all in areas containing fill materials consisting of steel-mill slag and coal-mine wastes, had sulfate concentration greater than $250 \mathrm{mg} / \mathrm{L}$. Only one bedrock well in the western area of West Virginia near the Ohio River alluvium had a sulfate concentration greater than $250 \mathrm{mg} / \mathrm{L}$.

Drillers' logs indicate that although fill is present at some localities from Kenova to Waverly, it is not as widespread nor as thick as in the northern area. The type of material that comprises this fill is not described in the logs. This relative lack of fill probably accounts for the lower sulfate concentration of ground water in the Ohio River alluvium of the western versus northern area.

Figure 4.3.4-1 shows the areal distribution of sulfate for the project area. Sulfate concentration ranged from 4 to $310 \mathrm{mg} / \mathrm{L}$ for all wells. The median sulfate concentration of ground water from alluvial wells was $54 \mathrm{mg} / \mathrm{L}$, and the median sulfate concentration of ground water from bedrock wells was $24 \mathrm{mg} / \mathrm{L}$. 
EXPLANATION

A $\bigcirc$ Alluvial well

B $\bigcirc$ Bedrock well

R O Radial Collector

DISSOLVED SULFATE, IN

MILLIGRAMS PER LITER

$0 \cdot 0-50$

$\theta 51-100$

O 101-250

$>250$

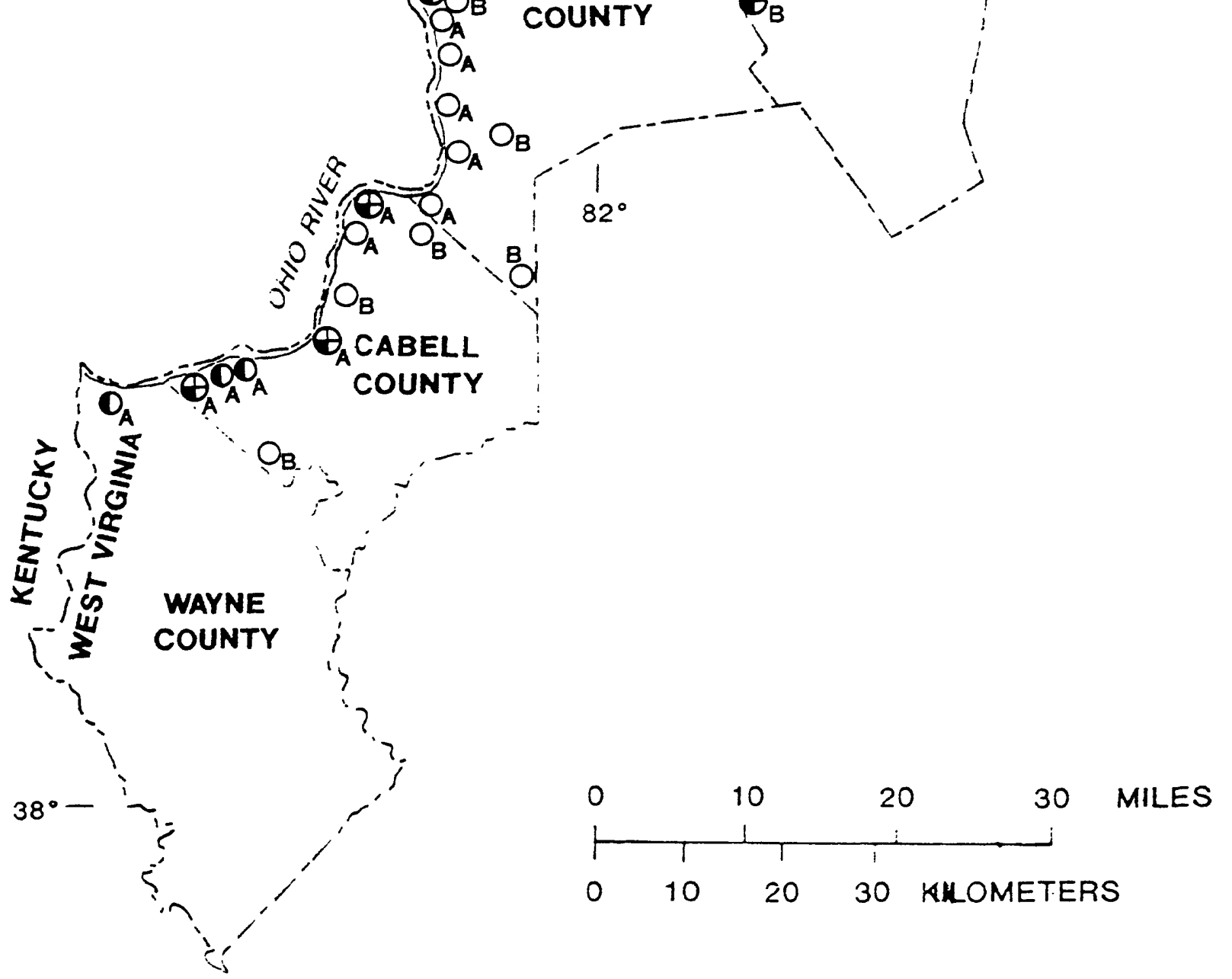

Figure 4.3.4-1 . - Areal distribution of dissolved sulfate. 
4.3.5 Contaminants

CONTAMINANTS EXCEEDED STATE DRINKING-WATER

LIMITS IN SOME WELLS

samples.

Barium, phenol, or nitrate concentrations exceeded State drinking-water limits in 7 of 42 ground-water

Drinking-water limits, as established by the West Virginia State Board of Health (1981) for contaminants, were exceeded in 7 of 42 ground-water samples (fig. 4.3.5-1). Contaminant limits were exceeded as follows: barium, two wells; phenols, three wells; and nitrate, two wells. Contaminants analyzed that did not exceed drinking-water limits in any well were arsenic, cadmium, copper, lead, mercury, selenium, silver, and zinc.

Concentration of barium ranged from 44 to $2,500 \mu \mathrm{g} / \mathrm{L}$; and phenol ranged from less than 1 to $20 \mu \mathrm{g} / \mathrm{L}$. Median concentration for barium in public- water supplies of the United States was reported to be $43 \mu \mathrm{g} / \mathrm{L}$ (Durfor and Becker, 1964). Higher concentration of barium is associated with brines or with water that has an elevated chloride concentration (Hem, 1959). Phenols in water are the result of industrial pollution and are toxic (Doll and others, 1963).

Concentration of nitrate ranged from less than 0.10 to $19 \mathrm{mg} / \mathrm{L}$. Elevated concentration of nitrate in ground water is the result of agricultural pollution from feedlots and fertilizer. Two of the sampled wells had excessive nitrate concentration. Fertilizer had been applied to adjacent fields near one well (13 mg/L of nitrate). The other well (19 $\mathrm{mg} / \mathrm{L}$ of nitrate) was about 100 yards from a cattle feedlot. This well was cased and seated in bedrock at about 100 feet with perforated casing between 80 to 85 feet. The nitrate from the feedlot had percolated through approximately 80 feet of alluvium to reach the open section of this well. This is evidence that the alluvium is recharged by precipitation that falls directly on the alluvial flood plain.

\subsection{Relation to Ground-Water Movement \\ CHEMICAL QUALITY OF GROUND WATER PROVIDES \\ INFORMATION ON GROUND-WATER MOVEMENT AND RECHARGE}

Results of water-quality analyses indicate that (1) ground water flows from the adjacent hills toward the Ohio River and (2) precipitation is the major source of recharge to the alluvium.

Ground water flows from the adjacent hills toward the Ohio River. This is supported by changes in the chemical composition of ground water along the flow paths. The mean hardness of ground water from wells drilled into the bedrock is as follows: Bedrock underlying hilltops-$280 \mathrm{mg} / \mathrm{L}$, bedrock underlying hillsides--300 mg/L, and bedrock underlying tributary valleys-$110 \mathrm{mg} / \mathrm{L}$. The decrease in ground-water hardness from hilltop and hillside wells to tributary valley wells is probably due in part to sodium-calcium exchange. As water moves toward the valleys, it comes into contact with minerals having exchangeable sodium. Sodium has a higher exchange rate than calcium; thus, calcium ions in the ground water are exchanged for sodium ions. 
CONCENTRATION LIMITS

FOR SELECTED CONTAMINANTS

IN MILLIGRAMS PER LITER:

$\begin{array}{lc}\text { Barium } & 1 \\ \text { Copper } & 1 \\ \text { Nitrate } & 10 \\ \text { Zinc } & 5\end{array}$

IN MICROGRAMS PER LITER:

$\begin{array}{lc}\text { Arsenic } & 50 \\ \text { Cadmium } & 10 \\ \text { Lead } & 50 \\ \text { Mercury } & 2 \\ \text { Phenols } & 1 \\ \text { Selenium } & 10 \\ \text { Silver } & 50\end{array}$

\section{0}

10

2

50

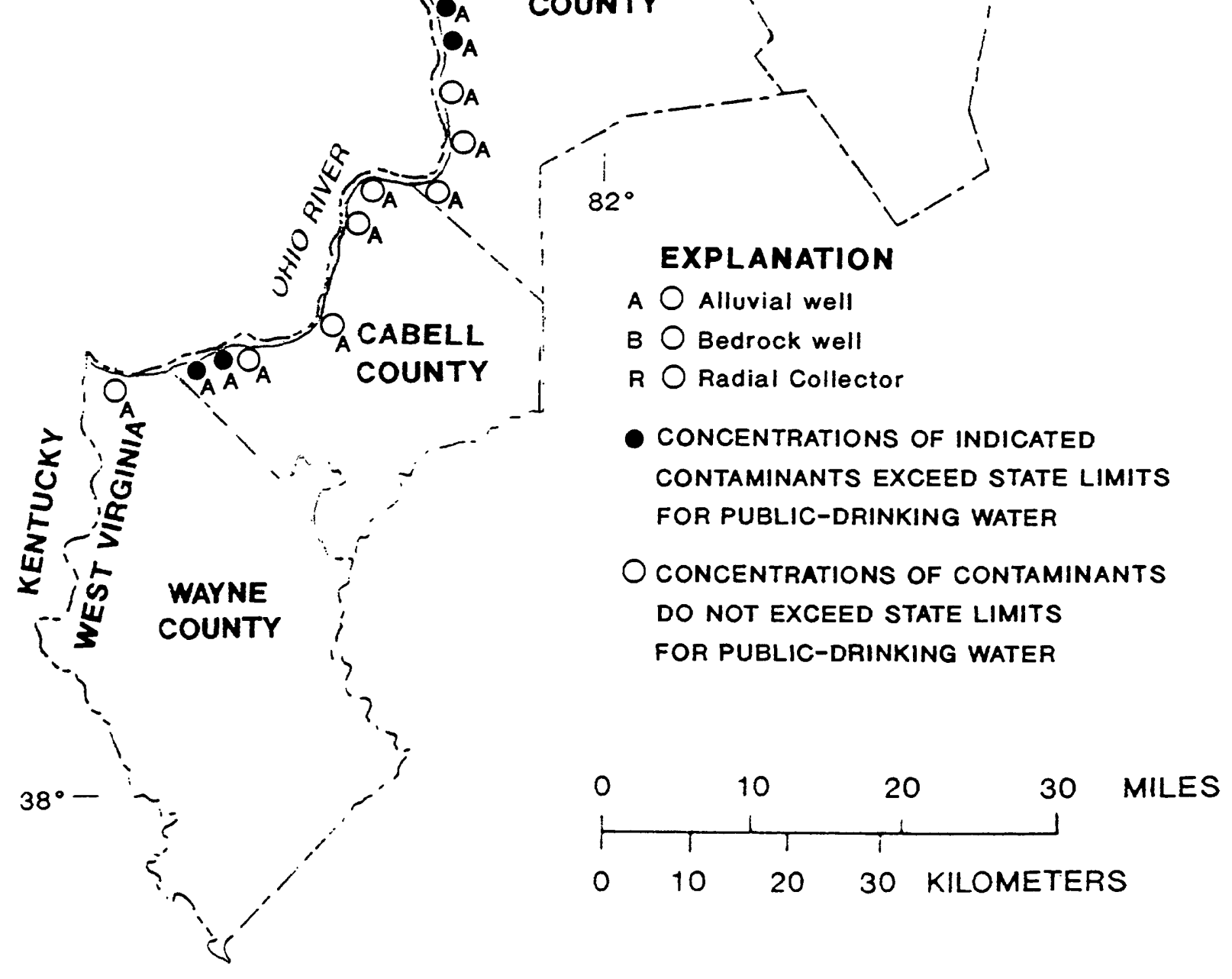

Figure 4.3.5-1. - - Areas where selected contaminant concentration exceeds established State limits (West Virginia State Board of Health, 1981). 
Large concentrations of nitrate in water in the alluvium where feedlots are located and where fertilizers are applied suggest that precipitation is a significant source of recharge to the alluvium. Feedlots and fertilizers are a major source of the nitrate that contaminates ground water. Two wells drilled in the alluvium in agricultural areas had high nitrate concentrations of $19 \mathrm{mg} / \mathrm{L}$ and $13 \mathrm{mg} / \mathrm{L}$. Fill material composed of mining and industrial waste on the Ohio River flood plain also can be a source of sulfate to ground water, but this is not a problem in the reach of the Ohio River between Kenova and Waverly.

The trilinear water-analysis diagram in figure 4.4-1 shows the general chemical character of the water from the bedrock, alluvium, and Ohio River. The Ohio River samples plot separately with little overlap with the samples from alluvial and bedrock wells. The alluvial and bedrock groundwater samples also show very little overlap. This is probably because some of the bedrock wells drilled on the flood plain are too deep (almost 300 feet) to show ground water mixing across the alluvium and bedrock contact, which is approximately 70 feet below land surface. Ground-water samples from these deeper bedrock wells do not represent the ground-water mixing that is probably occurring between bedrock and alluvium. 


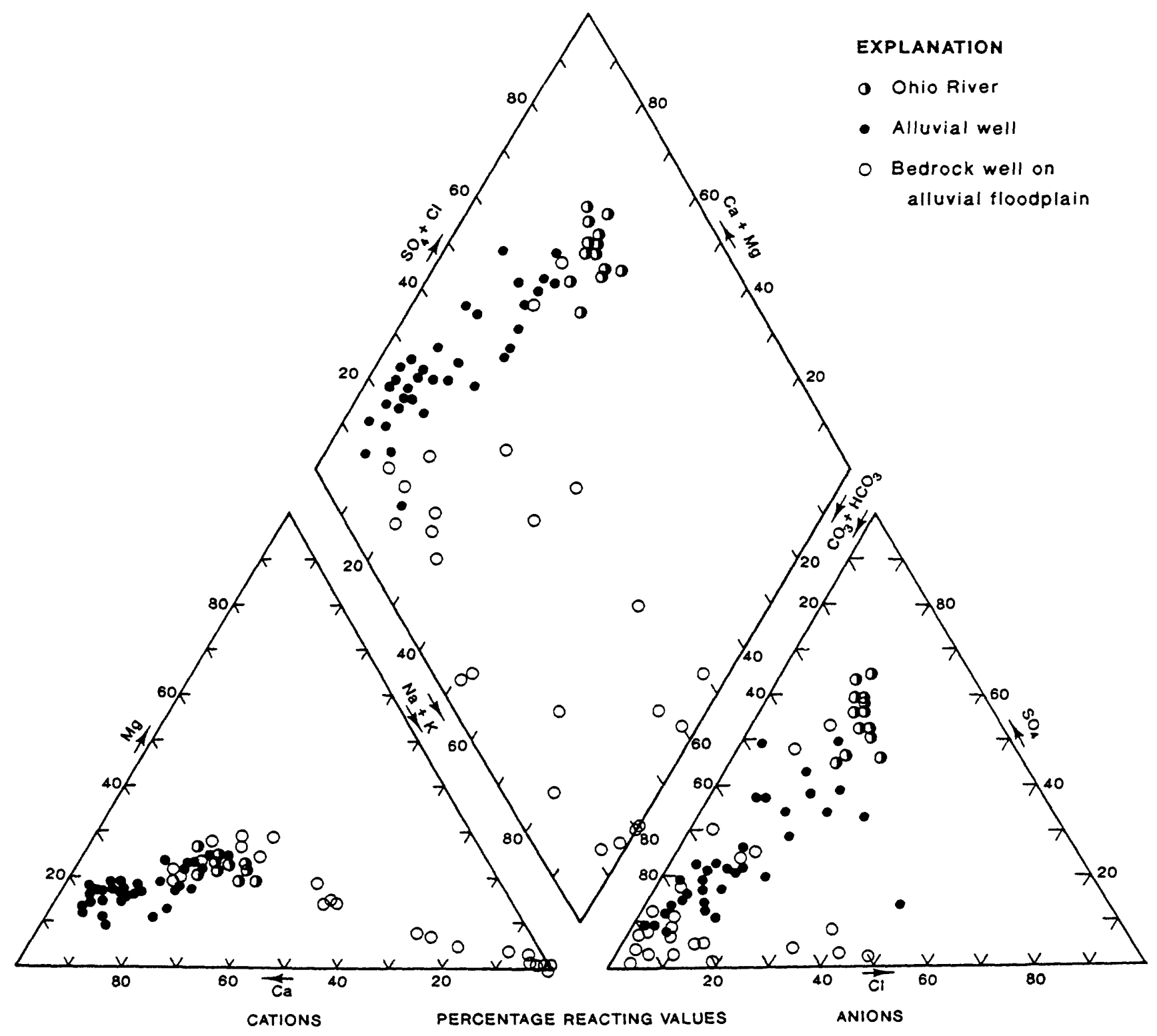

Figure 4.4-1. - - Trilinear water-analysis diagram of water samples from the alluvium, bedrock, and Ohio River. 


\subsection{SUMMARY}

Ground-water reserves in the study area are contained in two aquifer systems. The largest is the system of fractures in the consolidated rock that underlies the entire study area, and the other is the narrow band of alluvium that borders the Ohio River. Ground-water use in Cabell, Jackson, Mason, Wayne, and Wood Counties was at least 5.5 billion gallons in 1980 for public supply, mining, and domestic purposes.

The consolidated rock that crops out in the study area is of Pennsylvanian or Permian age and includes in ascending order the Pottsville Group, Allegheny Formation, Conemaugh Group, Monongahela Group, and Dunkard Group. Ground-water yields from these rock units are typically low for most wells in the study area. The only major geologic structure is the north-trending Burning Springs anticline in eastern Wood County. The alluvial deposits of Quaternary age are limited mostly to the flood plain of the Ohio River, but are the most productive aquifer system in the area. The lower part of the alluvial deposits consists of sand and gravel of glacial outwash origin and is overlain by clay and silt interspersed with sand stringers. In some areas, the tributary streams have deposited gravel deltas where they enter the valley of the Ohio River.

The alluvium is recharged by the following sources: (1) Precipitation on the flood plain, (2) inflow from fractures and bedding-plane partings in the bedrock beneath and adjacent to the alluvium, (3) inflow from tributary streams through gravel deltas, and (4) induced inflow from the river. Precipitation is more likely to recharge alluvial and bedrock aquifers during the months of November through April.

Drinking-water limits recommended by the West Virginia State Board of Health were exceeded in places by concentrations of iron, manganese, sulfate, nitrate, barium, and phenols. Hardness exceeded $120 \mathrm{mg} / \mathrm{L}$ in 78 percent of the samples. Chemical quality can help explain ground-water movement and recharge. Hardness decreases as the ground water moves through the bedrock from hills to valleys. Nitrate leached from fertilizers and feedlots appears in alluvial wells on the flood plain, indicating that precipitation is a significant source of recharge to the alluvium. 


\subsection{DEFINITION OF TERMS}

Confined ground water---Confined ground water is under pressure significantly greater than atmospheric, and its upper limit is the bottom of a bed of distinctly lower hydraulic conductivity than that of the material in which the confined water occurs (Lohman and others, 1972).

Hydraulic conductivity.--A medium has a hydraulic conductivity of unit length per unit time if it will transmit in unit time a unit volume of ground water at the prevailing viscosity through a cross section of unit area, measured at right angles to the direction of flow, under a hydraulic gradient of unit change in head through unit length of flow (Lohman, 1972).

Hydraulic gradient.--The hydraulic gradient is the change in static head per unit of distance in a given direction (Lohman and others, 1972).

Porosity.--The porosity of a rock or a soil is its property of containing interstices or voids and may be expressed quantitatively as the ratio of the volume of its interstices to its total volume (Lohman and others, 1972).

Semiconfinement.--The distinction between confined and unconfined water is entirely gradational. The term semiconfined is used for the intermediate conditions. The material overlying an aquifer may be semipermeable so that water is only semiconfined (Davis and DeWiest, 1966).

Specific capacity.--The specific capacity of a well is the rate of discharge of water from the well divided by the drawdown of water level within the well (Lohman and others, 1972).

Specific discharge.--The specific discharge, or specific flux, for ground water is the rate of discharge of ground water per unit area measured at right angles to the direction of flow (Lohman and others, 1972).

Specific retention.--The specific retention of a rock or soil is the ratio of the volume of water which the rock or soil, after being saturated, will retain against the pull of gravity to the volume of the rock or soil (Lohman and others, 1972).

Specific yield.--The specific yield of a rock or soil is the ratio of the volume of water which the rock or soil, after being saturated, will yield by gravity to the volume of the rock or soil (Lohman and others, 1972).

Storage Coefficient.--The storage coefficient is the volume of water an aquifer releases from or takes into storage per unit surface area of the aquifer per unit change in head (Lohman and others, 1972).

Transmissivity.--Transmissivity is the rate at which water of the prevailing kinematic viscosity is transmitted through a unit width of the aquifer under a unit hydraulic gradient (Lohman and others, 1972).

Unconfined ground water.--Unconfined ground water is water in an aquifer that has a water table (Lohman and others, 1972). 


\subsection{SELECTED REFERENCES}

American Public Health Association, Inc., 1960, Standard methods for the examination of water and wastewater (11th Edition): New York, $626 \mathrm{p}$.

Bader, J.S., 1984a, Ground-water hydrology of the Guyandotte River basin, West Virginia: West Virginia Department of Natural Resources, map report, scale 1:250,000, 1 sheet. 1984b, Ground-water hydrology of the Tug Fork and Twelvepole Creek basins, West Virginia: West Virginia Department of Natural Resources, map report, scale 1:250,000, 1 sheet.

Bader, J.S., Chisholm, J.L., Bragg, R.L., and Downs, S.C., 1989, Water resources of the Guyandotte River basin, West Virginia: West Virginia Geological and Economic Survey River Basin Bulletin 7, $130 \mathrm{p}$.

Bader, J.S., Mathes, M.V., and Runner, G.S., 1989, Water resources of Tug Fork of Big Sandy River basin, West Virginia, Kentucky, and Virginia, and Twelvepole Creek basin, West Virginia: West Virginia Geological and Economic Survey River Basin Bulletin 8, 113 p.

Bader, J.S., and others, compilers, 1973, Selected references, ground-water contamination, the United States of America and Puerto Rico: U.S. Geological Survey Open-File Report 74-225, 103 p.

Bain, G.L., and Friel, E.A., 1972, Water resources of the Little Kanawha River basin, West Virginia: West Virginia Geological and Economic Survey River Basin Bulletin 2, 122 p.

Bentall, Ray, compiler, 1963, Methods of determining permeability, transmissibility and drawdown: U.S. Geological Survey Water-Supply Paper 1536-l, p. 243-341.

Cardwell, D.H., Erwin, R.B., and Woodward, H.P., compilers, 1968, 1968 Geologic map of West Virginia: West Virginia Geological and Economic Survey Map, scale 1:250,000.

Carlston, C.W., and Graeff, G.D., Jr., 1955, Ground-water resources of the Ohio River valley in West Virginia, pt. III of Geology and economic resources of the Ohio River valley in West Virginia, 1956: West Virginia Geological and Economic Survey v. XXII, p. 1-131.

Chang, Mingteh, Lee, Richard, and Dickerson, W.H., 1976, Adequacy of hydrologic data for application in West Virginia: West Virginia University Water Research Institute Bulletin 7, series 78 , no. 8-3, 1978, p. 78 and 84 .

Clark, W.E., Chisholm, J.L., and Frye, P.M., 1976, Water resources of the Upper New River basin, West Virginia: West Virginia Geological and Economic Survey River Basin Bulletin 4,87 p.

Crain, L.J., 1966, Ground-water resources of the Jamestown area, New York, with emphasis on the hydrology of the major stream valleys: New York Conservation Department, Water Resources Commission, Bulletin 58, $167 \mathrm{p}$.

Cross, A.T., and Schemel, M.P., 1956, Geology of the Ohio River valley in West Virginia, pt. I of Geology and economic resources of the Ohio River valley in West Virginia, 1956: West Virginia Geological and Economic Survey v. XXII, p 1-149.

Davis, R.W., and Matthews, E.W., 1983, Chloroform contamination in part of the alluvial aquifer, southwest Louisville, Kentucky: U.S. Geological Survey Water-Supply Paper 2202, 25 p.

Davis, S.N., and DeWiest, R.J.M., 1966, Hydrogeology: New York, John Wiley and Sons, Inc., 463 p.

Deutsch, Morris, Dove, G.D., Jordan, P.R., and Wallace, J.C., 1966, Ground-water distribution and potential in the Ohio River basin, in Ohio River basin comprehensive survey, v. VI, Appendix E, ground water: The Corps of Engineers, U.S. Army Engineer Division, Ohio River, Cincinnati, Ohio, report, 197 p., 32 plates.

Doll, W.L., Meyer, Gerald, and Archer, R.J., 1963, Water resources of West Virginia: West Virginia Department of Natural Resources, Division of Water Resources Report, 134 p. 
Dove, G.D., and Wallace, J.C., 1966, Preliminary survey of ground-water distribution and potential in the Ohio River basin, sub-drainage area 5, Little Kanawha and Kanawha River basins (including southside drainage area to the Ohio River between Marietta and Point Pleasant), in Ohio River basin comprehensive survey, v. VI, Appendix E, ground water: The Corps of Engineers, U.S. Army Engineer Division, Ohio River, Cincinnati, Ohio, report, p. 5-1 to 5-18, 1 plate.

Durfor, C.N., and Becker, Edith, 1964, Public water supplies of the 100 largest cities in the United States, 1962: U.S. Geological Survey Water-Supply Paper 1812, 364 p.

Fenneman, N.M., and Johnson, D.W., 1946, Physical divisions of the United States: U.S. Geological Survey Map prepared in cooperation with Physiographic Commission, U.S. Geological Survey, scale 1:7,000,000. Reprinted 1964.)

Ferrell, G.M., 1984, Ground-water hydrology of the minor tributary basins of the Kanawha River, West Virginia: West Virginia Department of Natural Resources, map report, scale 1:250,000, 1 sheet.

Foster, J.B., 1980, Fresh and saline ground-water map of West Virginia: West Virginia Geological Survey Map WV-12, scale 1:250,000, 4 plates.

Gallaher, J.T., and Price, W.E., Jr., 1966, Hydrology of the alluvial deposits in the Ohio River Valley in Kentucky: U.S. Geological Survey Water-Supply Paper 1818, 80 p.

Grimsley, G.P., 1910, [Detailed geologic report of] Pleasants, Wood, and Ritchie Counties: West Virginia Geological Survey County Report, 352 p., 21 plates.

Grubb, H.F., 1975, Simulated drawdown for selected well fields in the Ohio River alluvial aquifer: U.S. Geological Survey Water-Resources Investigations 2-74, 38 p.

Grubb, H.F., and Zehner, H.H., 1973, Aquifer diffusivity of the Ohio River alluvial aquifer by the flood-wave response method: U.S. Geological Survey Journal of Research, v. 1, no. 5, SeptemberOctober 1973, p. 597-601.

Haught, O.L., 1955, Oil and gas report and map of Pleasants, Wood, and Ritchie Counties, West Virginia: West Virginia Geological and Economic Survey Bulletin 11, 21 p.

Heath, R.C., 1983, Basic ground-water hydrology: U.S. Geological Survey Water-Supply Paper 2220, $84 \mathrm{p}$.

Hem, J.D., 1959, Study and interpretation of the chemical characteristics of natural water: U.S. Geological Survey Water-Supply Paper 1473, 269 p.

1960, Some chemical relationships among sulfur species and dissolved ferrous iron: U.S. Geological Survey Water-Supply Paper 1459-C, 73 p.

1960, Restraints on dissolved ferrous iron imposed by bicarbonate, redox potential, and pH: U.S. Geological Survey Water-Supply Paper 1459- B, 55p.

1963, Chemical equilibria and rates of manganese oxidation: U.S. Geological Survey WaterSupply Paper 1667-A, 64 p.

1964, Deposition and solution of manganese oxides: U.S. Geological Survey Water-Supply Paper 1667-B, $42 \mathrm{p}$.

1970, Study and interpretation of the chemical characteristics of natural water, $2 \mathrm{~d}$ ed.: U.S. Geological Survey Water-Supply Paper 1473, 363 p.

1972, Chemical factors that influence the availability of iron and manganese in aqueous systems: The Geological Society of America Special Paper 140, p. 17-24.

Hobba, W.A., Jr., compiler, 1980, Ground-water hydrology of the Little Kanawha River basin, West Virginia: West Virginia Geological and Economic Survey Map WV-10, 1 sheet.

Jeffords, R.M., 1945, Ground-water conditions along the Ohio Valley at Parkersburg, West Virginia: West Virginia Geological Survey Bulletin 10, $57 \mathrm{p}$. 
Kazmann, R.G., Jeffords, R.M., and Schaefer, E.J., 1943, River-bed recharge to Quaternary alluvium bordering the Ohio River near Point Pleasant, West Virginia: U.S. Geological Survey Open-File Report, $110 \mathrm{p}$.

Kernodle, J.M., 1977, Theoretical drawdown due to simulated pumpage from the Ohio River alluvial aquifer near Siloam, Kentucky: U.S. Geological Survey Water-Resources Investigations 77-24, $39 \mathrm{p}$.

Krebs, C.E., 1911, [Detailed geologic report of] Jackson, Mason, and Putnam Counties: West Virginia Geological Survey County Report, 387 p., 31 plates.

1913, [Detailed geologic report of] Cabell, Wayne, and Lincoln Counties: West Virginia Geological Survey County Report, 483 p., 26 plates.

Lohman, S.W., 1972, Ground-water hydraulics: U.S. Geological Survey Professional Paper 708, 70 p.

Lohman, S.W., and others, 1972, Definitions of selected ground-water terms-- revisions and conceptual refinements: U.S. Geological Survey Water-Supply Paper 1988, 21 p.

McCue, J.B., Lucke, J.B., and Woodward, H.P., 1939, Limestones of West Virginia: West Virginia Geological Survey, v. XII, 560 p.

Munson, W.C., 1966, Estimating consumptive use, Munson P.E., index method, in Methods for estimating evapotranspiration: American Society of Civil Engineers Irrigation and Drainage Specialty Conference, Las Vegas, Nevada, November 1966, p. 65-107.

National Oceanic and Atmospheric Administration October 1973-November 1983, Climatological data, West Virginia: National Climatic Center, Asheville, North Carolina. (Issued monthly.) 1977, Climate of West Virginia: Asheville, North Carolina, $19 \mathrm{p}$.

1982, Monthly normals of temperature, precipitation, and heating and cooling degree days 195180, West Virginia: Asheville, North Carolina, $10 \mathrm{p}$.

Norris, S.E., 1970, The effect of stream discharge on streambed leakage to a glacial outwash aquifer: U.S. Geological Survey Professional Paper 700- D, p. 262-265.

Norris, S.E., and Eagon, H.B., Jr., 1971, Recharge characteristics of a watercourse aquifer system at Springfield, Ohio, in Ground Water: v.9, no. 1, p. 30-41.

Norris, S.E., and Fidler, R.E., 1969, Hydrogeology of the Scioto River valley near Piketon, southcentral Ohio: U.S. Geological Survey Water-Supply Paper 1872, 70 p.

Overbey, W.K., Jr., 1961, Oil and gas report and map of Jackson, Mason, and Putnam Counties, West Virginia: West Virginia Geological and Economic Survey Bulletin 23, 26 p.

Patchen, D.G., 1982, Oil and gas activity in West Virginia, 1970-1979: West Virginia Geological and Economic Survey Circular C-29, 187 p.

Pettyjohn, W.A., 1971, Water pollution by oil-field brines and related industrial wastes in Ohio: The Ohio Journal of Science 71 (5), September 1971, p. 257-269.

Price, P.H., Hare, C.E., McCue, J.B., and Hoskins, H.A., 1937, Salt brines of West Virginia: West Virginia Geological Surveỳ, v. VIII, 203 p.

Rorabaugh, M.I., 1946, Ground-water resources of the southwestern part of the Louisville area, Kentucky: U.S. Geological Survey Open-File Report, 39 p. 1956, Ground water in northeastern Louisville, Kentucky: U.S. Geological Survey Water-Supply Paper 1360-B, 69 p.

Shultz, R.A., 1984, Ground-water hydrology of the minor tributary basins of the Ohio River, West Virginia: West Virginia Department of Natural Resources, map report, scale 1:250,000, 1 sheet.

Stevens, H.C., and Lessing, Peter, 1982, Water use in West Virginia for 1980: West Virginia Geological and Economic Survey Circular C-27, 31 p. 
Wallace, J.C., Shamsi, R.A., and Deutsch, Morris, 1966, Preliminary survey of ground-water distribution and potential in the Ohio River basin, sub-drainage area 7, Guyandotte, Big Sandy, and Little Sandy River basins (including southside:drainage area to the Ohio River and Ohio River alluvium between Point Pleasant and Maysville), in Ohio River basin comprehensive survey, v. VI, Appendix E, ground water: The Corps of Engineers, U.S. Army Engineer Division, Ohio River, Cincinnati, Ohio, report, p. 7-1 to 7-13, 1 plate.

West Virginia State Board of Health, 1981, Public water-supply regulations: $47 \mathrm{p}$.

Whitesides, D.V., and Ryder, P.D., 1969, Effects of pumping from the Ohio River valley alluvium between Carrolton and Ghent, Kentucky: Kentucky Geological Survey Information Circular 18, $20 \mathrm{p}$.

Wilmoth, B.M., 1966, Ground water in Mason and Putnam Counties, West Virginia: West Virginia Geological and Economic Survey Bulletin 32, 152 p.

Wyrick, G.G., and Borchers, J.W., 1981, Hydrologic effects of stress-relief fracturing in an Appalachian valley: U.S. Geological Survey Water-Supply Paper 2177, 51 p. 